\title{
Le Pont de Londres: interactions between monetary and prudential policies in cross-border lending
}

\author{
Matthieu Bussière ${ }^{1}$, Robert Hills ${ }^{2}$, Simon Lloyd ${ }^{2}$, Baptiste Meunier ${ }^{1}$, \\ Justine Pedrono ${ }^{1,3}$, Dennis Reinhardt ${ }^{2}$, Rhiannon Sowerbutts ${ }^{2}$$$
\text { January 2020, WP \#753 }
$$

\begin{abstract}
We examine how euro area (EA) monetary policy and recipient-country prudential policy interact to influence cross-border lending of French banks. We find that monetary spillovers via cross-border lending can be partially offset by prudential measures in receiving countries. We then explore heterogeneities, specifically by bank size and location of the affiliate (French HQ vs. affiliates based in the UK). We find that the response of lending from French HQ to EA monetary policy is less sensitive to recipient-country prudential policy for systemic banks (GSIBs) than for non-GSIBs'. In contrast, the response of lending from GSIBs' affiliates in the UK is sensitive to recipient-country prudential policy. French GSIBs' crossborder lending from French HQ responds differently than lending from international financial centres. We also find evidence that French GSIBs channel funds towards the UK in response to EA monetary policy, in a manner dampened by global prudential policy setting. These findings suggest the existence of a 'London Bridge': conditional on EA monetary policy, French GSIBs adjust their funds in the UK depending on global prudential policies and, from there, lend to third-party countries according to local prudential policies. Finally, we have similar findings for all EA-owned banks UK affiliates, suggesting a broader relevance for the London Bridge.
\end{abstract}

Keywords: Monetary Policy, Prudential Policy, Policy Interactions, Spillovers, Financial Centre JEL classification: E52; F34; F36; F42; G18; G21

\footnotetext{
${ }^{1}$ Banque de France

2 Bank of England

3 Autorité de Contrôle Prudentiel et de Régulation (ACPR)

We are grateful to Galina Hale, Georgia Bush, Ambrogio Cesa-Bianchi, Maurizio Habib (discussants), Bill Francis and participants of International Banking Research Network (IBRN) meetings, the $3^{\text {rd }}$ Conference on Financial Stability at the Banco de México, the 5th BoE-BdF International Macroeconomics Workshop and the December 2019 IRC Expert Group Meeting on Financial Flows for useful comments.

Working Papers reflect the opinions of the authors and do not necessarily express the views of the Banque de France, ACPR or Bank of England. This document is available on publications.banque-france.fr/en
} 


\section{NON-TECHNICAL SUMMARY}

By combining the analysis of two unique confidential datasets, we examine how euro area (EA) monetary policy and recipient-country prudential policy interact to influence the crossborder lending of French banks from France and the UK. Unanticipated monetary policy shocks in a centre economy such as the EA are likely to lead to shifts in cross-border flows that could amplify or offset financial conditions abroad. International financial centres, such as the UK, are used to obtain, channel and optimise funding for large international banking groups - in particular those headquartered in continental Europe - implying that a share of those cross-border flows are likely to transit through them.

We find that French-owned banks significantly reduce (respectively increase) their international lending in response to tighter (respectively looser) EA monetary policy. Importantly, by allowing the prudential policy setting in recipient countries to interact with EA monetary policy, we find that prudential policy in the destination-country can partially offset this spillover. Specifically, countries with tighter prudential policy face a significantly smaller decline in their cross-border lending from France in response to a surprise euro area monetary policy tightening.

Benefiting from the granularity of our dataset, we then explore heterogeneities in that interaction, specifically the difference made by bank size and location of the affiliate (French headquarters vs. affiliates based in the UK, an international financial centre). For large French banking groups (GSIBs), the response of lending made from their French headquarters to EA monetary policy is not responsive to recipient-country prudential policies. In contrast, lending made by their affiliates located in London, a financial centre, does significantly respond to prudential policy in the final-destination country conditional on EA monetary policy. Conditioning on the effects of EA monetary policy, we then find that the cross-border lending of French GSIBs from France and from the UK is differently affected by recipientcountry prudential policy, suggesting that the two entities engage in different types of lending. The opposite pattern stands for non-GSIBs: the response of their lending made from their French HQ to EA monetary policy is sensitive to recipient-country prudential policy.

We finally find evidence that French GSIBs channel funds towards the UK in response to EA monetary policy, in a manner that is dampened by the global prudential policy setting.

Together, these findings suggest the existence of a two-arched 'London Bridge': conditional on EA monetary policy, French GSIBs adjust their funds in the UK in response to global prudential policies - first arch - and, from there, lend to third-party countries, responding to local prudential policies - second arch. Finally, we find evidence of a similar pattern - regarding the second arch - for all EA-owned bank affiliates in the UK, suggesting a broader relevance of the London Bridge.

Our findings suggest that prudential policies can help to insulate against the spillovers of centre-country monetary policy. From the perspective of smaller French non-GSIB crossborder lending, prudential policy offsets spillovers directly through lending from France. While, for larger French GSIBs, recipient-country prudential policy more strongly dampens fluctuations in cross-border lending channelled through international financial centres, such as London. 


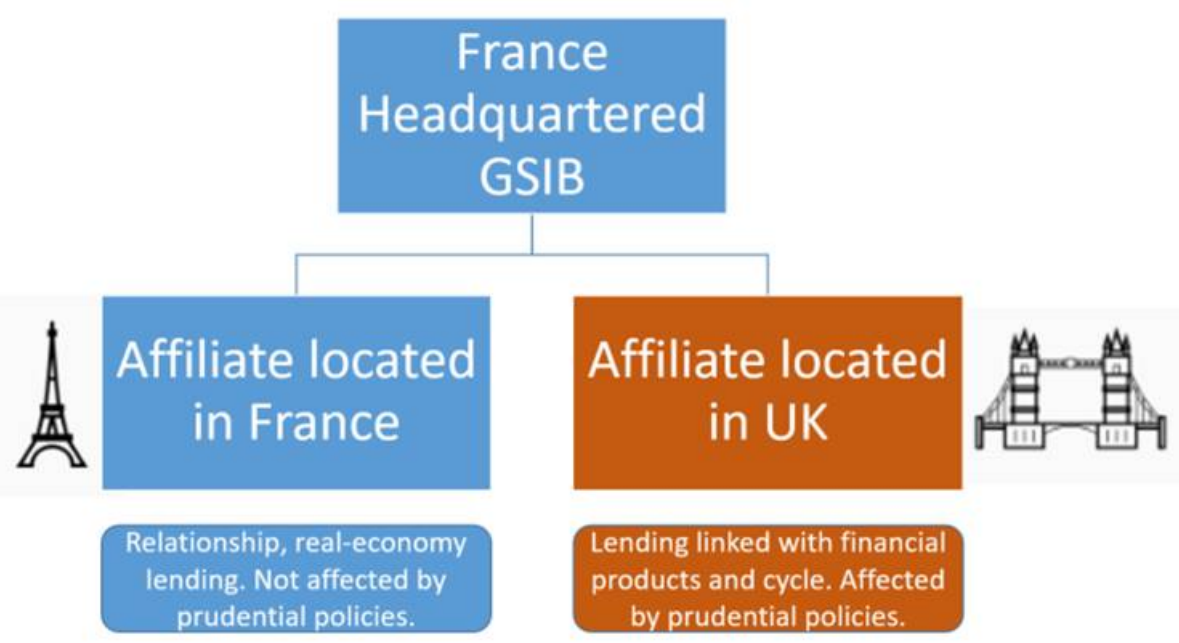

\section{The London Bridge : les effets de l'interaction entre politiques monétaires et prudentielles sur les prêts transfrontaliers}

\section{RÉSUMÉ}

Cet article examine comment la politique monétaire en zone euro et les politiques prudentielles des pays tiers interagissent et influencent la dynamique des prêts des banques françaises vers ces pays de destination. Les résultats indiquent que les spillovers de politique monétaire via le crédit bancaire sont en partie contrebalancés par la politique prudentielle des pays de destination. Nous analysons aussi comment la taille et la localisation des filiales influencent l'interaction. Ainsi, la réaction du crédit transfrontalier des banques systémiques (G-SIB) françaises à la politique monétaire en zone euro est moins sensible aux mesures prudentielles que celle des non G-SIB. De plus, les prêts transfrontaliers des G-SIB françaises depuis leur filiale au Royaume-Uni réagissent significativement à la politique monétaire de la zone euro et à la politique prudentielle des pays de destination à l'inverse de leurs prêts depuis la France. In fine, les crédits transfrontaliers des G-SIB depuis la France et depuis le Royaume-Uni répondent donc différemment à la politique monétaire de la zone euro et aux politiques prudentielles des pays de destination. Ce papier montre enfin qu'en cas d'action monétaire en zone euro, les G-SIB françaises ajustent leurs fonds vers le Royaume-Uni en fonction des politiques prudentielles dans le reste du monde. Tout cela suggère l'existence d'un «London Bridge effect » pour les G-SIB françaises : après un choc monétaire en zone euro, elles ajustent leurs fonds au Royaume-Uni en fonction des politiques prudentielles mondiale et de là, engagent du crédit transfrontalier vers les pays tiers en fonction des mesures prudentielles locales. Enfin, une analyse sur les autres pays européens suggère l'existence d'un «London Bridge effect » pour l'ensemble des grandes banques de la zone euro.

Mots-clés : Politique Monétaire, Politique Prudentielle, Prêts Bancaires, Centre Financier

Les Documents de travail reflètent les idées personnelles de leurs auteurs et n'expriment pas nécessairement la position de la Banque de France, de l'ACPR ou de la Bank of England. Ils sont disponibles sur publications.banque-france.fr 


\section{Introduction}

As global financial markets and banking systems become increasingly integrated, the spillover effects of monetary policy, for emerging markets in particular, become more acute (e.g. Carney, 2019). This increase in financial integration means that a large amount of funds flows from 'centre economies' to the rest of the world. More generally, a rich literature studying the high degree of co-movement in capital flows, asset prices and credit growth in the world economy-the 'global financial cycle-identifies centre-country monetary policy as an important driver of the cycle (Gerko and Rey, 2017). Unanticipated monetary policy shocks in those economies are likely to lead to shifts in cross-border flows that could amplify or offset financial conditions abroad. International financial centres, ${ }^{1}$ such as the UK, are used to obtain, channel and optimise funding of large international banking groups, implying that a share of those cross-border flows are likely to transit through them. But how can recipient countries protect themselves against potentially destabilising monetary policy changes in centre countries?

In this paper, we study the role of recipient-country prudential policies in offsetting monetary policy spillovers via cross-border lending. Using confidential data on the cross-border lending of French-owned banks based in France, we show that French-owned banks significantly reduce their international lending in response to tighter euro area (EA) monetary policy. Importantly, though, by allowing the prudential policy setting in recipient countries to interact with EA monetary policy, we find that prudential policy can offset this spillover. Specifically, countries with tighter prudential policy face a significantly smaller decline in their cross-border lending from France in response to a surprise EA monetary policy tightening.

Benefiting from the granularity of the French data, we explore bank heterogeneity in the crossborder interactions of monetary and prudential policy. Focusing on the size of the French banking groups, we find that the response of cross-border lending of French Global Systemically Important Banks (GSIBs) - a proxy for larger banking groups-to EA monetary policy is less strongly offset by recipient-country prudential policies than for non-GSIBs.

Importantly, we also find evidence for locational heterogeneity in cross-border interactions between monetary and prudential policies, identifying differences between banks' lending from their headquarters and via financial centres. We achieve this by uniquely co-utilising the French dataset and a similarly confidential dataset of UK-based banks' cross border lending. Using this data, we distinguish (i) the lending of a French banking group from their French headquarters to the rest of the world, (ii) the lending of a French banking group from their French headquarters to the UK only, and (iii) the lending of French banking groups from their London offices to the rest of the world.

\footnotetext{
${ }^{1}$ A 'financial centre' designates a place of major financial activities, with a significant share of it performed by foreign international banking groups. The UK is the financial centre in this paper, but the category more broadly encompasses Hong Kong, Singapore, Switzerland, etc. In contrast, a 'centre economy' designates a country whose domestic economic developments can have sizeable impact on the rest of the world. In this paper, France (as part of the EA more broadly) represents this category.
} 
Conditioning on the effects of EA monetary policy, we find that the cross-border lending of large French banks from the UK is more strongly offset by recipient-country prudential policy than the cross-border lending of large French GSIBs from France, suggesting that the two entities engage in qualitatively different types of lending.

In addition, we find evidence of a 'London Bridge' in cross-border lending. In response to a EA monetary policy tightening, the cross-border lending of large French GSIBs from their French headquarters to the UK declines significantly, an effect that is dampened by the overall setting of prudential policy in the rest of the world (i.e. in all countries excluding France and the UK). Taken together these findings suggest that large French banks seek to channel funds via London, an international financial centre, to engage in different types of cross-border lending to those carried out from their French headquarters. Our unique combined dataset allows us to show evidence of the two arches of the London Bridge: from the French headquarters to London-based affiliates, and from there to the rest of the world.

Finally, by extending the London Bridge to other EA-owned banking group affiliates in the UK, we find evidence that their cross-border lending is influenced by recipient-country prudential policy, conditional on EA monetary policy shocks. This serves to illustrate that the London Bridge is not specific to French banking groups in the UK, and suggests that it is more widely relevant and linked to the UK's role as an international financial centre.

Together, our findings suggest that prudential policies can help to insulate against the spillovers of centre-country monetary policy. From the perspective of smaller French non-GSIB cross-border lending, prudential policy offsets spillovers through its effects on lending directly from France. On the other hand, for larger French GSIBs, recipient-country prudential policy more strongly dampens fluctuations in cross-border lending channelled through international financial centres, such as London.

Related Literature We contribute to four main strands of the literature. First we contribute to the literature on cross-border banking, financial centres and the global financial cycle. Rey (2013) argues that credit flows are particularly procyclical. In this paper we show that there is heterogeneity amongst credit flows, with the flows of smaller French banks from their headquarters, as well as the flows of larger French banks from their affiliates located in a financial centre, being more responsive to policies than the flows of larger French banks from their headquarters. The latter corroborates the finding of Bruno and Shin (2014) that bank-to-bank flows, where regional banks borrow from global banks, have played a major role in the expansion of domestic lending. Banks from foreign countries set up offices in a financial centre to engage in a broad range of financial activities (Kindleberger 1974; Gehrig 2000), including trading in financial markets, as well as clearing and settlement of payments and securities. Our paper indicates that international lending from a financial centre is more responsive to global factors, possibly benefiting from economies of scope. Specifically, we show that the cross-border lending of large French banks located in the UK responds to recipient-country prudential policies, conditioning on 
EA monetary policy, more strongly than the cross-border lending of large French banks from France.

We also contribute to the growing literature on banks as a transmitter of monetary policy spillovers. Bruno and Shin (2014, 2015a, 2015b) highlight bank leverage as a key channel in the transmission of monetary policy and cross-border bank capital flows. Berrospide et al. (2017) use data on bilateral bank claims and show that monetary policy is an important determinant of cross-border bank flows. Buch et al. (2019) summarises a cross-country effort by the International Banking Research Network to examine the effect of monetary policy spillovers-in particular EA, US, UK and Japanese monetary policy. Their key finding is that monetary policy has pervasive cross-border spillover effects via banks' lending to the real economy both in conventional and unconventional monetary policy periods.

We extend this literature by highlighting the role of prudential policy in receiving countries in offsetting some of these spillovers, therefore also contributing to the literature on interactions between monetary and prudential policies. Despite an abundant theoretical literature (e.g. Aghion and Kharroubi 2013; Unsal 2011), empirical assessments examining interactions in an international context are scarce. Some papers focus on specific prudential policy instruments or countries (e.g. Forbes et al. 2017; de Jonghe et al. 2016; Bruno and Shin 2014; de Marco and Wieladek 2016), while more systematic global analyses have a different scope to ours. For instance, Bremus and Fratszcher (2015) focus on syndicated loans, Takats and Temesvary (2017) only assess prudential policy interactions in response to the 2013 taper tantrum, and Coman and Lloyd (2019) assess how macrofinancial outcomes in emerging markets can be insulated against US monetary spillovers by domestic prudential policies.

Finally, we contribute to the literature studying the impact of regulation on bank flows (Buch and Goldberg 2017). Houston et al. (2012) use the Barth et al. (2004) survey on banking regulation and supervision and examine whether difference in bank regulations influenced bank capital flows and find evidence that banks transfer funds to markets with less stringent regulation. Reinhardt and Sowerbutts (2015) show that prudential policies, in particular capital regulation can be an important driver of cross-border banking flows, at least for the first year after the prudential regulation is enacted. An important contribution of our work is to focus on the interaction effect of regulation, rather than its direct effect on cross-border banking flows.

Our paper extends on all of these literatures by studying monetary and prudential policy interactions via cross-border bank lending over a broad time period (2000-2017) and covering a range of prudential instruments captured by the Cerutti et al. (2017) dataset. As a result, our findings provide robust evidence for the stabilising role of prudential policy in response to global shocks.

Roadmap The remainder of the paper is organised as follows. Section 1 presents the main hypotheses we test in this paper. Section 2 details French and UK banking systems in order to highlight heterogeneous characteristics. Data and empirical specifications are presented in section 3, while section 4 presents our results. Section 5 concludes. 


\section{Section 1: Hypotheses}

Our prior is that a country that has taken more action to tighten prudential policies will be more insulated from external factors that could affect the domestic loan supply by, for instance, insulating banks' balance sheets against changes in asset values caused by a foreign shock. In particular, a country with tighter prudential policy ahead of a monetary policy shock in centre economies should face smaller volatility in capital flows through cross-border lending than a country with looser prudential policy.

While the usual aim of bank capital instruments is to ensure that banks are more resilient in a stress (BIS 2010), prudential policies also affect the cyclicality and level of bank lending behaviour. By ensuring that banks have more skin in the game, this should imply a more stable supply for loans. Borrower-targeted prudential policies such as LTV and LTI limits have also been shown to limit the cyclicality of lending (IMF 2011; Kuttner and Shim 2016) and usually apply even to direct borrowing from abroad (Reinhardt and Sowerbutts 2015); stabilising therefore the demand for loans from abroad.

We also assess the role of bank size, using GSIB status as a proxy for the size of the parent banking group in the French case, ${ }^{2}$ and bank nationality in our subsequent analysis. A large literature suggests that larger banks may be less affected by monetary policy shocks than smaller banks (e.g. Kashyap and Stein 2000). However, there is very little literature considering the size of the parent group itself and studying whether larger banks would be more or less affected by other countries' prudential policies than smaller banks. Our paper provides novel empirical evidence in this regard.

Our baseline hypothesis is that larger banks' cross-border lending is likely to be less sensitive to receiving-country prudential measures when adjusting to monetary policy. Larger banks may be able to lend abroad in a more informed way-maybe screening at a lower cost-and are generally involved in longer-term investment abroad-e.g. when granting a loan to a home-based multinational customer in order to support this client's international expansion. In contrast, small banks face higher screening costs and have fewer long-term international relationships, making their cross-border lending more responsive to monetary policy and, in turn, more sensitive to prudential policies in receiving countries.

This hypothesis interacts with the nationality of the bank affiliate. Long-term relationships are often most likely to be located at the bank's headquarters. For a large French-headquartered bank then, cross-border lending made from its headquarters in France is less likely to be responsive to EA monetary policy and recipient-country prudential policy than cross-border lending made from affiliates abroad. In particular, affiliates in major financial centres may concentrate on shorter-term lending. We then hypothesise that cross-border lending from a large French bank affiliate in London, conditional on EA monetary policy, may be more strongly offset by recipient-country

\footnotetext{
${ }^{2}$ As explained in more details in Section 3, the French banking sector is highly polarized, which allows us to distinguish "large international groups" from "domestically-focused" using the GSIB status. Such a proxy might however not be relevant for other countries.
} 
prudential policies, because this London affiliate would be where shorter-term lending decisions are made. In other words it is doing a different type of lending - to borrow from the capital flows literature, more like 'portfolio lending' than 'foreign direct investment'.

Note that the previous hypothesis pertains to large international banking groups-those able to establish a full-fleshed investment base in London-while for those smallest banks, the two types of lending would be done from France. However, we conjecture that the higher screening costs and their lower share of commitments with global-level firms would make their lending, on average, more responsive to monetary and prudential policies.

Figure 1 summarises our main hypotheses, highlighting our differing predictions for the responsiveness of the cross-border lending of French GSIBs from their headquarters vs. an international financial centre to recipient-country prudential policy, conditional on a EA monetary policy impulse.

Figure 1 - Summary of Main Hypotheses

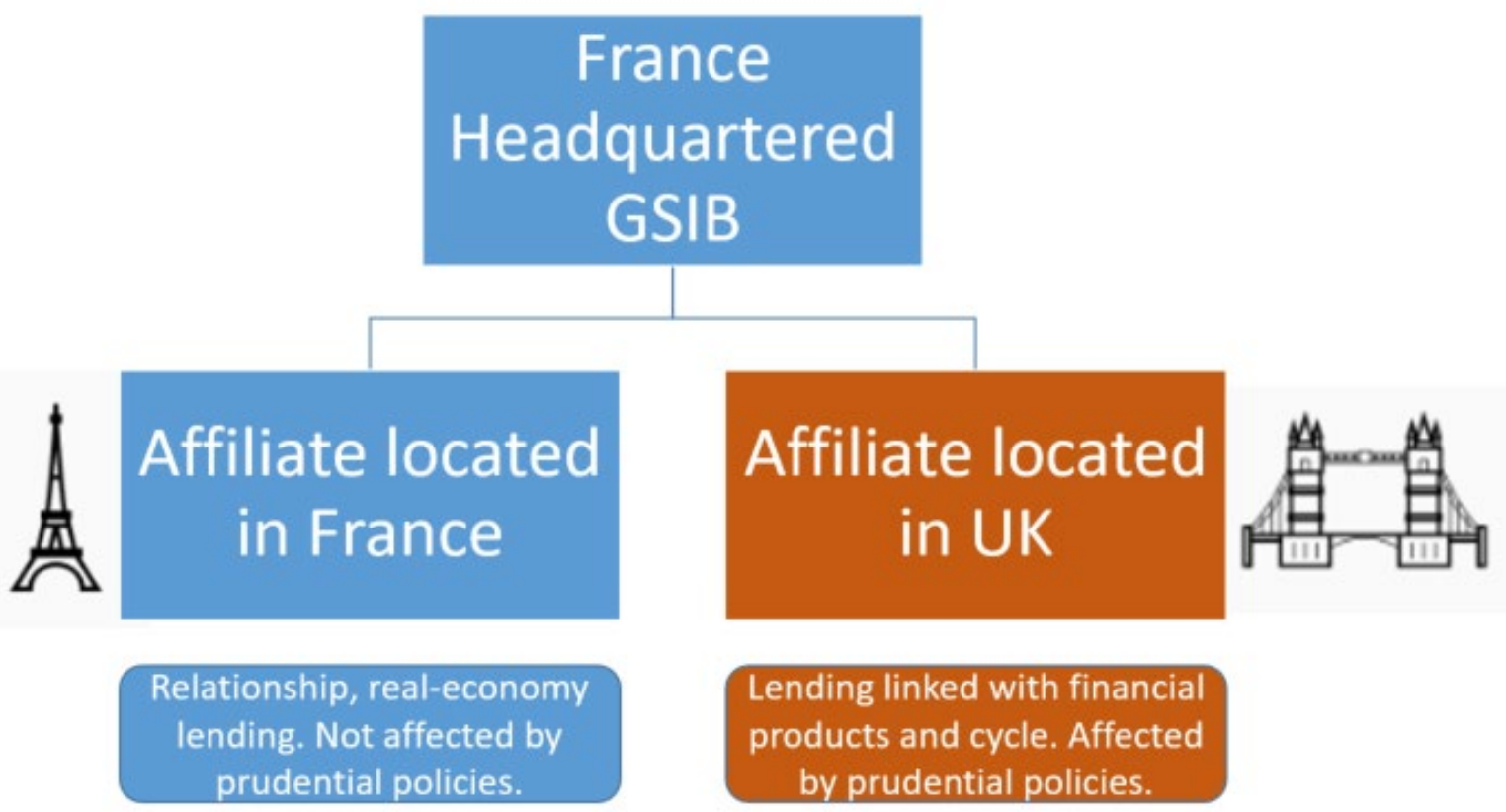




\section{Section 2: Overview of French and UK banking systems}

There are major differences between the French and UK banking systems, in particular in their degree of concentration and in the presence of international banks. We hypothesise that this heterogeneity is key to understanding the differential interactions between monetary policy spillovers and prudential policies across banking systems and different types of banks.

The French banking system is highly concentrated and dominated by domestic banks. In 2017, the six largest banking groups held 83\% of total banking system assets (ACPR 2018). Their significant size and their group structure make them systemic. Four out of the major six French banking groups have been defined as GSIBs. Since one of the criteria for determining whether a bank is a GSIB is the level of cross-jurisdictional assets and liabilities, this implies that these are amongst the most internationally active in the world. In addition to size - captured by total assets-GSIBs have a complex group structure, implying numerous affiliates located abroad.

Interestingly, while those GSIBs have an extensive network of affiliates in the UK, it is not the case for non-GSIBs. On average over 2010-2017, 6\% of the total affiliate network of French GSIBs was located in the UK, while the comparable figure for non-GSIBs was less than $1 \%$. This extensive network of French GSIBs' UK affiliates might indicate that the UK is not only an investment destination for those banking groups, but rather a larger node for international financial activities. Because these affiliates located in the UK are specialised in wholesale banking, foreign lending, and trading, this characteristic of GSIBs is especially relevant for understanding the effect of the 'London Bridge'. It also helps to explain the heterogeneity in cross-border lending: lending initiated by French affiliates located in France may react differently to monetary policy stance and prudential policies compared to French affiliates located in the UK.

On the other hand, the UK is a major financial centre with external liabilities over $250 \%$ of GDP. It is host to over 200 international banks, with a roughly even split between branches and subsidiaries. The UK stands out as one of the most international banking hubs with almost $50 \%$ of assets from foreign-owned banks, compared to less than $20 \%$ in the US or $4 \%$ in Japan. These foreign affiliates, a large share of which are from the EA, undertake a multitude of different activities, in particular investment banking and trading, but also foreign lending. For French banks, the UK is the second largest location abroad, just after the US, showing the importance of this financial centre for the French banking system.

While the UK banking system as a whole is highly diverse, many core activities are not. Retail and commercial lending in the UK is highly concentrated in five banks, four of which are UK headquartered, with the fifth headquartered in Spain. All but one of these UK banks are also GSIBs in the sample period meaning that they are not just lending extensively to UK borrowers but also to foreigners. ${ }^{3}$ There is a sixth UK headquartered GSIB which does very little UK lending.

\footnotetext{
${ }^{3}$ RBS and Lloyds were removed from the GSIB list in 2017 and 2013 respectively.
} 


\section{Section 3: Data and empirical framework}

\section{Section 3.1: Data}

\section{Banking system data}

Central to our analysis are two confidential datasets for UK and France-based banks' cross-border loans. The datasets are compiled by national banking supervisors where they are privately held and, as a consequence, used independently. It covers cross-border lending, disaggregated by bank and by recipient country, ${ }^{4}$ permitting a rich specification of fixed effects to control for potential confounding factors in our regressions. Banks are identified by name and interbank code (CIB) meaning that we are able to identify when an entity is part of a larger banking group, and what the nationality of that banking group is.

Throughout our study the dependent variable of interest captures the cross-border lending of each bank to different recipient countries at a quarterly frequency. This is the same for both the French and the UK datasets.

Due to differences in the data collection process, however, the sample periods for the UK and French data do differ. The French data runs from 2000Q1 to 2013Q2. The UK data has recently been updated and, in the main body of the paper, we report results using a sample running from 2000Q1 to 2017Q4. We favour this longer sample to maximise the number of prudential policy actions in our dataset. Nevertheless, our UK results are robust to using a common sample vis-à-vis the French dataset, and we report these in an Appendix.

Control variables Both datasets contain a wide range of information on UK and France-based banks' balance sheets which vary across banks and time. As the literature shows that the impact of prudential instruments depends on bank characteristics (e.g. Buch and Goldberg 2017), we use a range of this information as control variables in our regression framework. The definitions of the balance sheet variables are:

- $\log$ (Total Assets), assets deflated by GDP deflator. It controls for the overall size of the bank, an important control variable across banking literature since size can imply preferential access to external funding due to "too big to fail" status.

- Capital Ratio, percentage of banking organisation's regulatory Tier 1 risk-based capital to asset ratio. This is a potentially important to control by the capital "quality" because the adjustment of loans in response to change in deposits - induced by monetary policy shocks - could be impaired by capital constraints.

\footnotetext{
${ }^{4}$ While the general idea remains the same-to keep banks with enough international presence-there are slight differences in data cleaning. For France, banks with presence in at least 5 external countries and with over 1 billion foreign assets in total are kept. The UK data contains all bank-country observations above $\$ 10$ million in cross-border lending. In addition, a continuity condition is imposed on French data: to qualify, an observation must be included in a group of at least 8 consecutive data points.
} 
- Liquid Asset Ratio, percentage of a bank's asset portfolio that is liquid; a key control as it reflects a bank's ability to adjust its asset side. In Kashyap and Stein (2000), monetary policy has a greater impact on banks with lower buffers of liquid assets.

- Core Deposits Ratio, percentage of the banking organisation's balance sheet financed with core deposits. This variable captures the ex-ante extent to which banks access alternative sources of funding outside of deposit taking. A bank with a high ratio can build on a more stable and more reliant funding source

- Commitment share, percentage of unused commitments over assets. As a substantial amount of loans is made under commitments, this is an essential control.

- International share, share of bank's foreign assets over total assets which measures the degree of internationalisation of the bank.

Summary statistics Table 1 reports summary statistics for the cross-border lending of French banks in France. For comparison, Table 2 reports comparable summary statistics for French-owned banking affiliates' cross-border lending from the UK.

Table 1 highlights an important difference between GSIBs and non-GSIBs in France, relevant for our study. In particular, the mean international share of French GSIBs is around 19\%, over 50\% more than the mean international share of French non-GSIBs, of around $12 \%$.

Comparing Tables 1 and 2 further highlights notable differences between the cross-border lending of French-owned banks from France vs. the UK. First, both the mean and standard deviation of cross-border lending growth from the UK is larger than from France. Mean lending growth from France is around 2\%, a fifth of the mean lending growth of French banks from the UK, hinting at the important role for international financial centres in channelling funds. The standard deviation of lending growth from the UK is over 50\% larger than from France too, suggesting that crossborder lending from the UK may indeed be more responsive to shocks and prevailing policy settings. Second, although some headline bank balance sheet characteristics of French banks in France vs. the UK are similar (e.g. log total assets, capital ratio), there is a marked difference in these banks' international share. In France, the average international share of a GSIB is just 19\%, compared to $70 \%$ for French-owned banks in the UK, suggesting that cross-border lending from financial centres like London may have a different flavour to the cross-border lending from bank headquarters.

To further summarise the data, Figures 2 and 3 plot the cross-border lending of French-owned banks from France and the UK, respectively, in 2013Q2. The heat maps highlight the cross-sectional coverage of cross-border lending vis-à-vis the rest of the world. Both plots illustrate that large shares of cross-border lending go to the US and other European economies. 
Figure 2 - Heat map of French banks' cross-border lending from France by recipient country, 2013Q2

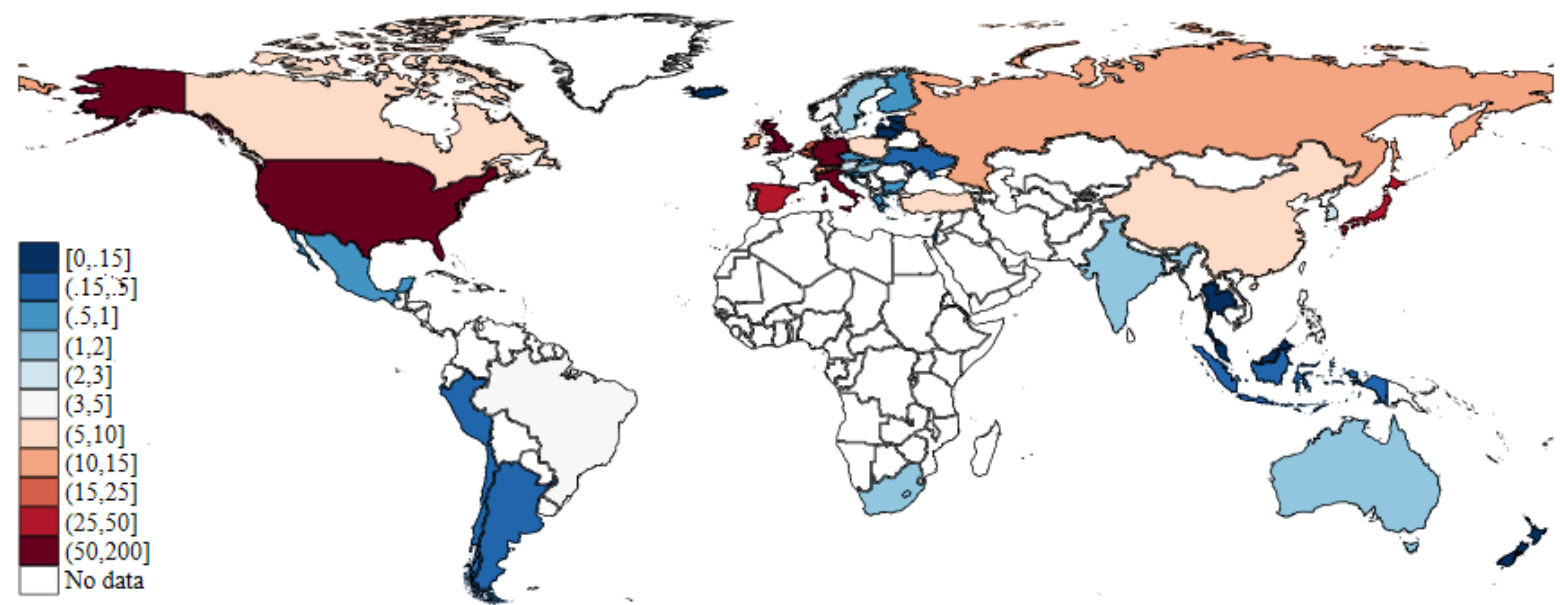

Notes. Heat map of French banks' cross-border lending from France by recipient country in 2013Q2. Figures are reported in billions of euros.

Figure 3 - Heat map of French-owned banks' cross-border lending from the UK by recipient country, 2013Q2

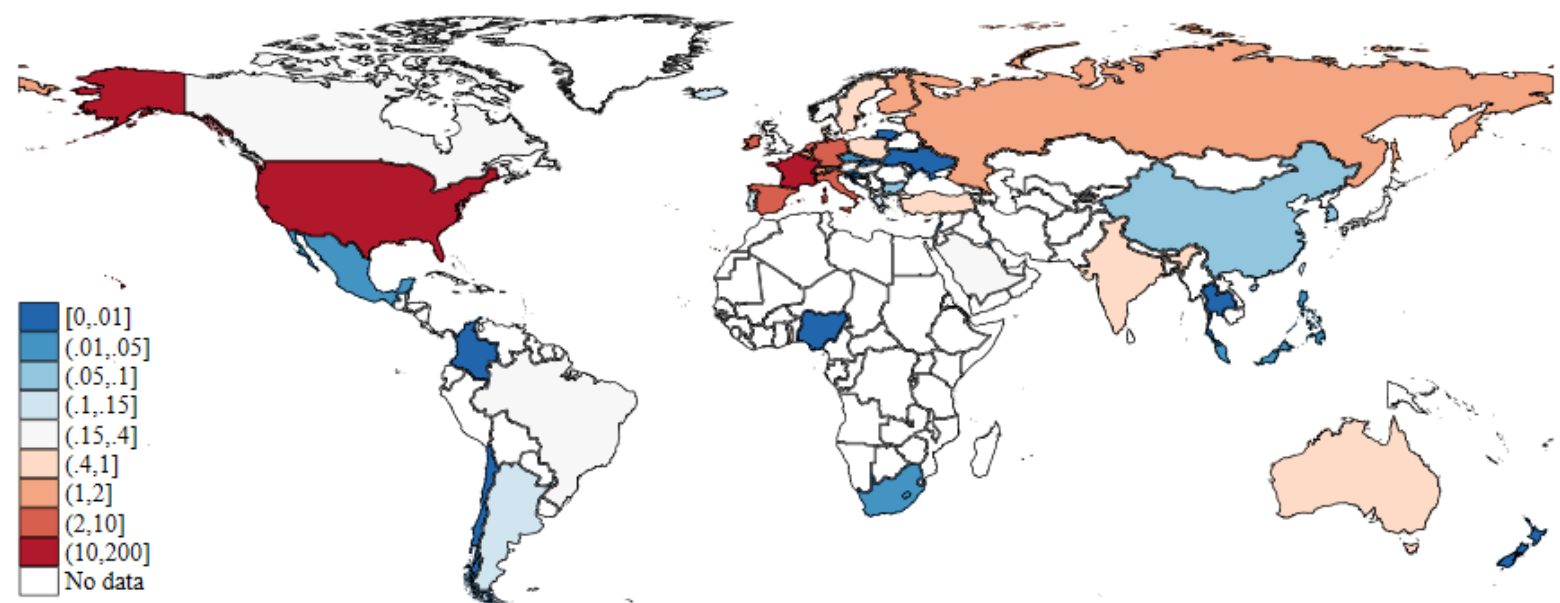

Notes. Heat map of French-owned banks cross-border lending from the UK by recipient country in 2013Q2. Figures are reported in billions of US dollars.

\section{Prudential policy dataset}

Data on country-level prudential policy measures is taken from the 2019 update of Cerutti et al. (2017). The data assigns the value of +1 to a given prudential policy if it was tightened in a specific period, the value of -1 if it was loosened, and 0 if no change occurred. Although limited information is provided on relative intensity of prudential change ${ }^{5}$, the main advantages of this dataset are a long time series (2000Q1-2017Q4), a wide country-coverage (64 countries), and broad span of prudential instruments ( 7 instruments covering both lender- and borrower-targeted measures). The

\footnotetext{
${ }^{5}$ For sectoral capital requirements and reserve requirements, the database however includes information on the intensity of policy changes as the index ranges from -3 to +5 .
} 
Cerutti et al. (2017) datasets spans the following instruments: general capital requirements, sectorspecific capital buffers, loan-to-value (LTV) ratio limits, reserve requirements for both foreign and local-currency deposits, interbank exposure limits, and concentration ratio limits.

To account for lags in the setting of prudential policies and their persistent effects on the financial sector, we cumulate prudential policy actions over a 2-year period. As in Coman and Lloyd (2019), who use the Cerutti et al. (2017) in a similar manner this choice balances a trade-off. On the one hand, the cumulation period needs to be sufficiently long to proxy persistence in the level of prudential policy and capture policy transmission and implementation lags. On the other, we want to avoid a cumulation period that is too long such that reversals in prudential policy suppress variation in our proxy. In our baseline proxy for prudential policy, we also exclude reserve requirements as, in some countries, these are used for monetary policy, not prudential, purposes. In particular, they have been used extensively in emerging economies as alternative to monetary policy in response to capital inflows (Claessens et al. 2013; IMF 2012, 2013; Montoro and Moreno 2011).

The heat map in Figure 4 demonstrates cross-sectional variation in our prudential policy proxy, depicting the cumulative sum of the number of prudential policy actions in each countryexcluding reserve requirements - in the period 2011Q3-2013Q2. ${ }^{6}$ In this period, both advanced economies - Switzerland, Canada and Sweden, for example — and emerging economies—-India and Peru-most intensely tightened their net overall prudential policy setting.

Figure 4 - Heat map of cumulated prudential policy actions by country, 2011Q3-2013Q2

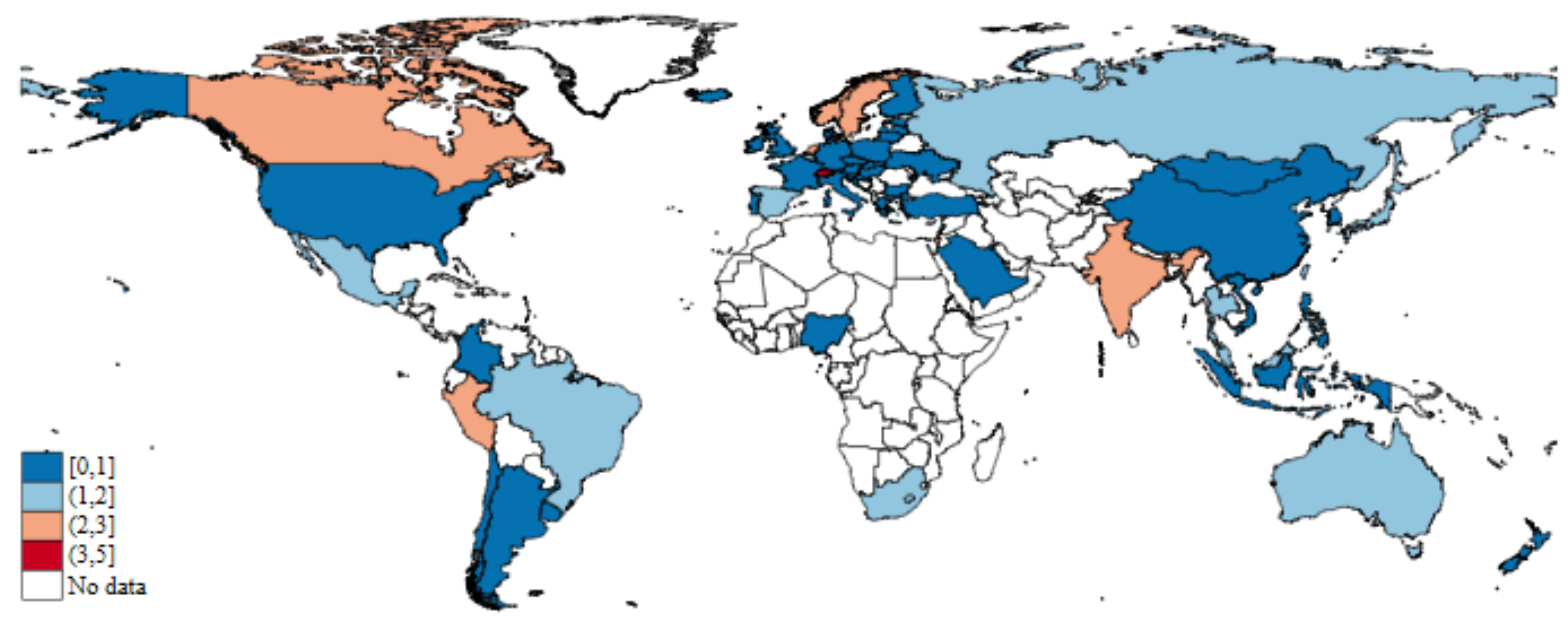

Notes. We sum all types of prudential policy actions, excluding reserve requirements, in a given quarter and country from the extended Cerutti et al. (2017) dataset. We then cumulate the prudential policy actions over a two-year period (2011Q3-2013Q2) to construct a proxy for the overall prudential policy setting over this time span. Importantly, this measure can take positive and negative values, although over this specific time period, all countries' prudential policy proxies happen to be weakly positive. Positive (negative) values indicate a net tightening (loosening) of overall prudential policy over the period.

\footnotetext{
${ }^{6}$ We choose this time period to match the dependent variable heat maps in Figures 2 and 3.
} 


\section{Monetary policy}

It is crucial that our measure of monetary policy is exogenous with respect to the dependent variable. In the context of our study, a pertinent concern is the influence of omitted third factors on EA monetary policy and cross-border lending of French banks. We use monetary policy surprises defined as the difference between realised and anticipated monetary policy during a short time window centred around monetary policy announcements as our measure of monetary policy (e.g. Kuttner 2001; Gürkaynak et al. 2005). These capture the "surprise" component of policy since the only substantive macroeconomic news within the window pertains to monetary policy. This helps us to overcome the potential endogeneity issue in that monetary policy may depend on bank lending, or both could be driven by omitted (and uncontrolled for) third factors.

The EA monetary policy surprises are constructed by Altavilla et al. (2019), and measure intraday moves in overnight indexed swap (OIS) rates around ECB policy announcements and press conferences. Again, we construct quarterly time series, we cumulate surprises in a given quarter. In our baseline regressions, we use surprises from the 6-month OIS tenor, which reflect both surprise changes in the immediate policy rate, but also changes in the expected 'timing' of future interest rate changes over the 6-month period. ${ }^{7}$ These surprises span our 2000Q1-2013Q2 (2000Q12017Q4) for the French (UK) cross-border bank lending data.

\section{Section 3.2: Empirical framework}

Our question of interest is how EA monetary policy surprises affect French banks' external lending and, in turn, the extent to which prudential policies taken in receiving countries affect this lending.

Our point of departure is a regression specification assessing EA monetary policy spillovers through French banks' external lending is:

$$
\Delta Y_{b, j, t}=\alpha_{0}+\sum_{k=0}^{K} \alpha_{1, k} M P_{t-k}^{E A}+\boldsymbol{\alpha}_{4} \boldsymbol{X}_{b, t-1}+\boldsymbol{\alpha}_{5} \boldsymbol{Z}_{j, t-1}+\boldsymbol{\alpha}_{6} \boldsymbol{G}_{t-1}+f_{b}+f_{j}+\epsilon_{b, j, t}
$$

$\Delta Y_{b, j, t}$ is the log change of cross-border lending by bank $b$ to country $j$ at quarter $t . M P_{t}^{E A}$ denotes the EA monetary policy surprise at time $t . X_{b, t-1}$ is a vector of time-varying bank control variables (see above). $Z_{j, t-1}$ includes other time-varying receiving-country control variables, which might co-move with domestic prudential policies-including controls for domestic demand, in our baseline specification we use lagged annual nominal GDP growth and credit growth. $f_{b}$ are bank fixed effects. $f_{j}$ are receiving country fixed effects. Because the main coefficient of interest in the above equation $\alpha_{1, k}$ loads on EA monetary policy, which is the same for all banks $b$ and receiving countries $j$, we cannot include time fixed effects in the regression. Nevertheless, to capture global

\footnotetext{
${ }^{7}$ In the Appendix, we demonstrate that our results are robust to the use of alternative EA monetary policy measures that may better capture the effects of EA unconventional monetary policies targeted at reducing longer-horizon yields. Nevertheless, we use the 6-month tenor as our benchmark for the EA as EA monetary policy has been less constrained by an effective lower bound than monetary policy in other advanced economies (e.g. US and UK), with the ECB's interest rate on its deposit facility falling negative in June 2014.
} 
time-varying factors that may contaminate our estimates of monetary policy spillovers, we include global macroeconomic controls $\boldsymbol{G}_{t}$ such as the VIX and measures of US and UK monetary policy surprises. Standard errors $\epsilon_{b, j, t}$ are clustered at the bank-time level.

When assessing the interactions of monetary policy with receiving country prudential policy $P r u_{j, t}^{\text {dest }}$, we alter our specification to include time fixed effects $f_{t}$. These time fixed effects absorb the direct effect of EA monetary policy spillovers and the global controls $\boldsymbol{G}_{t}$, but control for all possible globally time-varying factors that could otherwise contaminate estimate of the interaction coefficient of interest. The baseline specification for assessing the interaction is therefore:

$$
\begin{aligned}
\Delta Y_{b, j, t}=\alpha_{0}+ & \alpha_{2} \operatorname{Pru}_{j, t-K-1}^{\text {dest. }}+\sum_{k=0}^{K} \alpha_{3, k}\left(M P_{t-k}^{E A} \cdot \operatorname{Pru}_{j, t-K-1}^{\text {dest. }}\right)+\alpha_{4} \boldsymbol{X}_{b, t-1}+\alpha_{5} \boldsymbol{Z}_{j, t-1}+f_{b} \\
& +f_{j}+f_{t}+\epsilon_{b, j, t}
\end{aligned}
$$

In addition to the definitions above, $\operatorname{Pr} u_{j, t-K-1}^{\text {dest. }}$ is a measure of the stance of destination-country prudential policy. We include both the level of prudential policy actions, as well as its interaction with monetary policy. We include the former to account for the direct effects of prudential policy on recipient-country inflows. For instance, Reinhardt and Sowerbutts (2015) show that countries experience capital inflows for up to four quarters following a tightening in capital requirements.

As described above, our baseline measure cumulates all prudential policy actions, excluding reserve requirements, in a country over a two-year period. Importantly, we only account for prudential policy actions enacted prior to the EA monetary policy action of interest-reflected by the $t-K-$ 1 lag on the prudential policy measure. This setup prevents the possibility that our estimates capture a (potentially endogenous) response of receiving-country prudential policy in response to a EA monetary policy surprise. In our baseline specification, we investigate the four-period effect of monetary policy, i.e. $K=3$. So our prudential policy measure, $P r u_{j, t-4}^{\text {dest }}$ captures cumulated prudential policy actions in a country $j$ over two years from $t-11$ to $t-4 .^{8}$

The main coefficients of interest in the interaction regression are the $\alpha_{3, k}$, capturing how an additional prudential policy action stance in a receiving country interacts with monetary policy surprise.

In relation to our main hypotheses, we expect that a surprise EA monetary policy tightening will (on average) reduce external lending, reflected by $\hat{\alpha}_{1, k}<0$. In response to a surprise monetary policy, we also expect that a country with a tighter prudential policy stance prior to the surprisehigher $P r u_{j, t-K-1}^{\text {dest }}$ - should (on average) face a smaller negative spillover than a country with looser prudential policy, reflected by $\hat{\alpha}_{3, k}>0$. Given the $+1 /-1$ definition of $\operatorname{Pr} u_{j, t-K-1}^{\text {dest }}$, the coefficient $\alpha_{3, k}$ can be interpreted as the influence of an additional prudential policy tightening on the crossborder monetary spillover relative to its mean.

\footnotetext{
${ }^{8}$ In robustness analysis, we investigate different cumulation periods for prudential policy.
} 


\section{Section 4: Results}

\section{1: Baseline results}

Table 3 presents our baseline results for the lending of French banks from their headquarters. It summarises the spillover effects of EA monetary policy and the interaction with receiving-country prudential policy for French banks' cross-border lending, as well as a hybrid regression designed to provide some indication of the economic significance of our findings.

Column 1 demonstrates that a surprise EA monetary policy tightening significantly reduces French banks' cross-border lending growth from their headquarters. Here, we document cumulated monetary policy coefficients-i.e. $\sum_{k=0}^{K} \hat{\alpha}_{1, k}$ for $k=0,1,2,3$ - to emphasise the cumulative effect of a 1 percentage point EA monetary policy surprise on the average level of cross-border lending on impact $(k=0)$, after one quarter $(k=1)$, two quarters $(k=2)$ and three quarters $(k=3) .{ }^{9}$ The estimates indicate that a 1 percentage point surprise tightening of EA monetary policy reduces the average level of external lending by $25 \mathrm{pp}$ within the quarter.

Columns 3 presents our headline estimate of the interaction between recipient-country prudential policies with monetary policy for the cross-border lending of French banks from their headquarters. The prudential policy measure here sums all actions (excluding reserve requirements) over a twoyear period in advance of the monetary policy event. Again, we document the cumulated coefficients-i.e. $\sum_{k=0}^{K} \hat{\alpha}_{3, k}$ for $k=0,1,2,3$ - to isolate the average interaction effect on the level of cross-border lending. The $\sum_{k=0}^{K} \hat{\alpha}_{3, k}$ can thus be interpreted as the average interaction effect of each additional prudential policy tightening with the spillover from a 1 percentage point EA monetary policy tightening on the level of cross-border lending. Given the negative EA monetary policy spillover estimates-identified in column 1-the results in column 3 indicate that the spillover effects of a EA monetary policy tightening can be reduced by a tighter recipient-country prudential policy setting, in advance of the EA monetary policy impulse. Specifically, each additional prudential policy tightening can, on average, reduce the spillover from a EA monetary policy tightening shock on the level of cross-border lending from banks in France by around 31pp over a one-year period.

Direct comparison of the coefficient estimates from columns 1 and 3 is not possible, as the former omits time fixed effects $f_{t}$, while the latter does not. To illustrate the economic significance of our headline results, we estimate a hybrid version of our interaction regression, which includes the EA monetary policy variable $M P_{t-K}^{E A}$ as an additional explanatory variable, but omits time fixed effects to make this operational. In the absence of time fixed effects, we add lagged time-varying global control variables $\boldsymbol{G}_{t-1}$ to the regression specification. This permits concurrent estimation of the direct average EA monetary policy spillover coefficients $\hat{\alpha}_{1, k}$ and the interaction coefficients $\hat{\alpha}_{3, k}$ with the same set of controls. Because we omit time fixed effects, we do not rely on this hybrid

\footnotetext{
${ }^{9}$ The individual coefficient estimates-i.e. $\hat{\alpha}_{1, k}$ for $k=0,1,2,3$ - can instead be interpreted as the impact of a 1 percentage point EA monetary policy surprise on the average $k$-quarter-ahead growth rate of cross-border lending.
} 
specification for inference, instead we use it to compare the two coefficients to gauge the economic significance of our findings.

Column 2 presents the results of the hybrid regression. The results indicate that an additional prudential policy tightening, in advance of a EA monetary policy shock, can approximately annul the spillover effects of EA monetary via a specific channel of the shock's cross-border transmission, namely French banks' cross-border lending from their headquarters. Within a one-year horizon, the average spillover effect of a 1 percentage point EA monetary policy tightening peaks at $-0.36 \%$, and the maximal effect of an additional prudential policy tightening is to reduce this average spillover completely—by 37pp.

These results provide novel evidence about the role of prudential policy in partially offsetting the cross-border spillovers via international bank lending following EA monetary policy shocks.

\section{2: Bank size and GSIB affiliation}

Given these findings, we turn to asking: for which types of banks are these interactions strongest? In this sub-section, we continue to focus on the cross-border lending of French banks from their headquarters.

As detailed above in Section 1, there is an abundant literature on the importance of size. However, what may matter most is the size of the parent banking group rather than the size of the entity itself. Being an affiliate of a large banking holding company, such as a GSIB, implies that the affiliate is unlikely to be fully independent of its parent. Lending decisions observed at the bank level may, in fact, reflect the state of its parent-especially if the parent's headquarters is located in the same country as the affiliate. Our unconsolidated data allows us to test whether this is the case. We do so, by drawing on the classification of banking groups into GSIBs and non-GSIBs. In our context, the GSIB classification can then be interpreted as a proxy for isolating larger, more complex and more interconnected banking groups. As Table 1 emphasises, based on summary statistics of the raw data, GSIBs in France appear to have larger international exposures than non-GSIBs, even at an unconsolidated level. Nevertheless, the size of unconsolidated entities-measured by the average of (log) total assets-is not significantly different across the two groups.

In Table 4, we report interaction results for French banks cross-border lending, separating the banks with GSIBs parents from those with non-GSIB parents (columns 1 and 2). In turn, columns 3 and 4 show results for large banks (above EUR 100bn in assets) separated by whether they belong to a GSIB parent or not while columns 5 and 6 focus on small banks (below EUR 100bn assets) and GSIB affiliation.

We find a role for both size and GSIB affiliation. Interactions with receiving-country prudential polices are significant only for small banks which are not part of a larger GSIB group (column 6). Large banks are insignificantly affected by the prudential policy setting in recipient countries, conditional on a EA monetary policy shock, regardless of whether their parent is a GSIB or not. For small banks, entities that belong to a GSIB parent group also see no significant impact of recipient- 
country prudential policy on the response of their cross-border lending to a EA monetary policy shock.

All in all, this suggests that the size of the parent entity plays an important role. For GSIBs, whether small or large, the response of cross-border lending to a EA monetary policy impulse is insignificantly affected by the prudential policy setting in recipient countries. In contrast, the interaction is significant for smaller banks not associated with a GSIB parent. Therefore, our results underline a novel dimension of heterogeneity in cross-border lending between GSIBs and nonGSIBs. The size of an individual affiliate does not appear to be the sole determinant of cross-border policy interactions. The size, complexity and interconnectedness of the parent entity is also a significant factor.

\section{3: The 'London Bridge' of French GSIBs}

So far, our analysis has focused on the banking activities of French banks in France, but this is does not reflect all of the activities of French banking groups. Much of this is managed through affiliates located abroad, and especially in international financial centres like London. Sapir et al. (2017), Batsaikhan et al. (2017) and Kaya et al. (2018) demonstrate that French large banks have located a large share of their activities in wholesale banking in London-including directing lending towards the EA, as the heat map in Figure 3 reinforces. As noted above, there are likely to be economies of scope with other financial activities which are undertaken in the financial centre such as investment banking and trading; and this can explain why wholesale banking is undertaken from the UK affiliate and not from the French headquarters. This suggests that lending from the financial centre may be more responsive to the global policies than lending undertaken from the headquarters.

To test whether this is the case, we exploit the fact we have micro-level banking data for both France and the UK. Although we cannot match the two datasets-due to confidentiality-we can identify French-owned banks in the UK dataset. Given this, we estimate variants of our interaction regression on both datasets, in essence testing the presence of a double-arched 'London Bridge' in cross-border lending. The first arch of this bridge corresponds to cross-border lending from the French GSIBs' headquarters in France towards its UK affiliates, while the second arch connects these French-owned UK affiliates to the rest of the world.

To test the first arch, we use the French dataset to focus on cross-border loans of GSIBs from France to the UK, and not towards other geographies. In addition, we adapt our interaction regression to account for the global prudential policy setting, rather than the UK-specific setting. To do so, we define $\mathrm{Pru}_{j, t-4}^{R o W}$ as the proxy for the global prudential policy setting across the world, defining it as the cross-country average of prudential policy proxies $\operatorname{Pr}_{j, t-4}$ in each time period, excluding the UK and French measures. ${ }^{10}$ We use this global proxy to reflect the hypothesis that French GSIBs' lending to the UK is likely to onward-channelled to the rest of the world, thus implying that the

\footnotetext{
${ }^{10}$ In the context of this regression, the individual UK and French prudential policy proxies are absorbed in the time fixed effects.
} 
global measure better reflects the prudential policy setting in the ultimate destination for funds than the UK prudential policy measure.

To test the second arch, we use the UK dataset, and focus on French-owned banks' cross-border lending from the UK. In this setting, we can estimate our interaction regression using the countryspecific prudential policy proxies $\mathrm{Pru}_{j, t-4}$. We focus on the same EA monetary policy shock throughout.

Figure 5 provides a visual summary of the London Bridge, depicting (i) lending from French bank headquarters to the UK and (ii) the lending of French affiliates in the UK to the rest of the world. We present the results of each arch in the subsequent two sub-sections, respectively. Broadly our results indicate that the spillovers via French-owned banks' cross-border bank lending following a EA monetary policy shock are more sensitive to recipient-country prudential policy when lending emanates from London-based affiliates than when it comes from French headquarters.

Figure 5 - Summary of the London Bridge

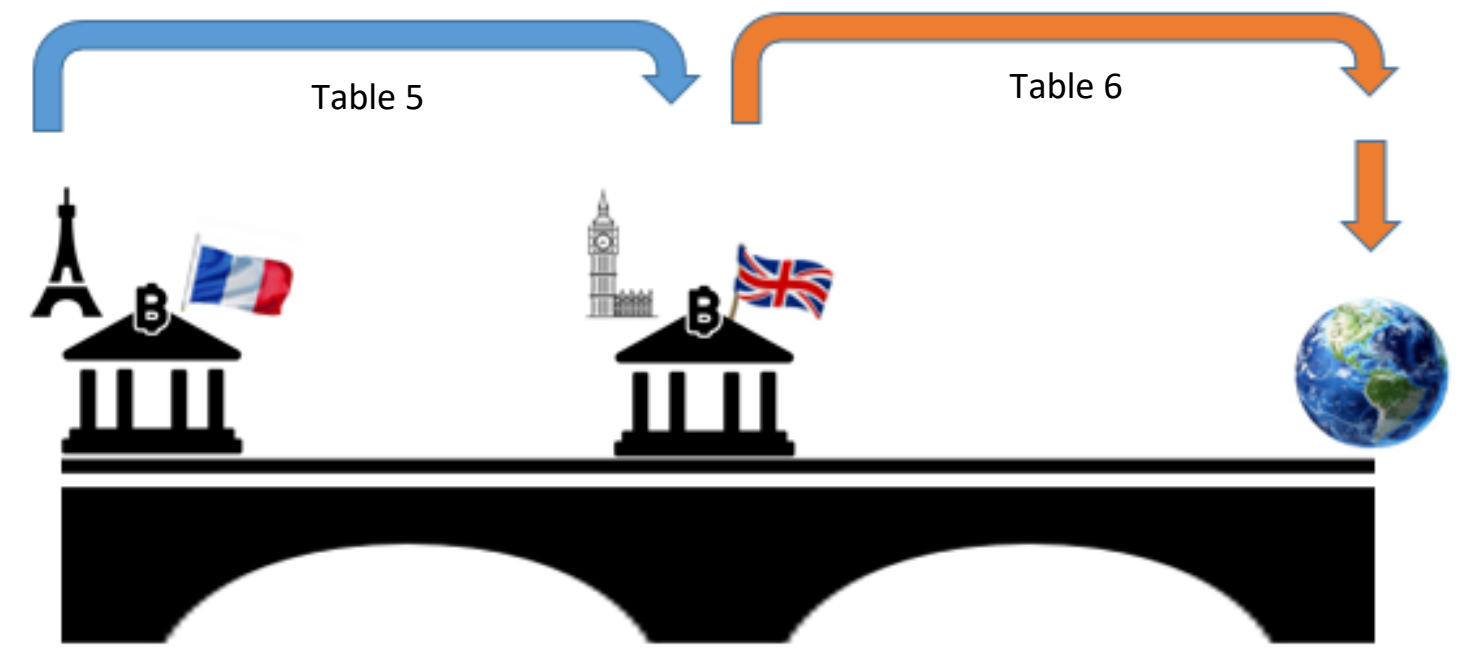

\subsection{1: Arch 1: Cross-Border Lending from French Headquarters to the UK}

Results for the first arch are presented in Table 5, documenting interaction estimates for banks with GSIB and non-GSIB parents in columns 1 and 2, respectively.

Column 1 demonstrates that the spillover of EA monetary policy via GSIB-lending from France to the UK is sensitive to the global prudential policy setting. This is consistent with the hypothesis that French GSIBs channel funds via the UK onto third-country destinations.

In contrast, column 2 highlights that the average spillover of EA monetary policy via non-GSIBs does not respond significantly to global prudential policy. This chimes with the hypothesis that non-GSIBs do not channel funds to the UK as a base for external lending. 


\subsection{2: Arch 2: Cross-Border Lending from the UK}

We now turn to the 'second arch' of the London Bridge, examining how cross-border lending by bank affiliates in the UK depend on prudential policies in recipient economies, conditional on EA monetary policy shocks. Results for this are presented in Table 6. ${ }^{11}$ Columns 1 and 2 focus on the activities of French-owned banks in the UK. Column 1 demonstrates that, following a EA monetary policy shock, the cross-border lending of French banks in the UK can be offset by the prudential policy actions in recipient counties. Moreover, in column 2, we show that this result is not driven by French banks' lending from the UK to the EA, which could be driven by the direct effects of EA monetary policy. When excluding this cross-border lending, prudential policy continues to significantly offset the French banks' lending response, conditional on EA monetary policy.

Combined with the results in Table 5, these results demonstrate the existence of a 'London Bridge' in French GSIBs' lending. When cross-border lending by French banks emanates from the UK, the responsiveness of this lending to EA monetary policy is significantly dampened by recipientcountry prudential policy. But this offsetting mechanism is not significant for the cross-border lending of French GSIBs' lending from their headquarters.

To further investigate the London Bridge, column 3 repeats this exercise above for all EA bank affiliates in the UK. This is designed to highlight the fact that the Bridge is not specific to French GSIBs, indicating that it is a feature of London's role as an international financial centre. Comparing column 3 with column 1, we can see that other EA banks in the UK behave similarly to the French banks in that the response of their foreign lending to EA monetary policy interacts with prudential policy, albeit more persistently.

In column 4, we carry out a placebo test, assessing the extent to which the cross-border lending response of UK-owned banks in the UK to EA monetary policy depends on recipient-country prudential policy. Comparing column 4 in Table 6 to Table 4, we can see that the UK-owned banks in the UK behave similarly to the French GSIBs in France in that their foreign lending does not interact with recipient-country prudential policy, conditioning on EA monetary policy. This is not surprising as the UK banks are mainly GSIBs and so would be expected to behave similarly to French GSIBs. While we are unable to repeat the full French exercise for other countries' banks given the confidential nature of the data used, these results suggest that the results above are not particular to the French case and are likely to hold for a broader set of banks.

\footnotetext{
${ }^{11}$ In an appendix, we demonstrate that all of our headline results reported in Table 6 are robust to the use of an alternative EA monetary policy surprise (to account for unconventional monetary policies that affected longer-horizon yields in the EA) and the inclusion of reserve requirements in our overall prudential policy proxy. We also demonstrate that our headline results about French banks are robust to reduction of the UK data sample from 2000Q1-2017Q4 to 2000Q1-2013Q2, to match the timespan of the French dataset.
} 


\section{Section 5: Conclusion}

Using data on UK and France-based banks' external lending, we find that EA monetary policy has significant spillover effects, with a surprise tightening of monetary policy causing significant reductions in the external lending of banks in France. Our results indicate that prudential policy actions in countries that receive this cross-border lending can help to offset spillovers from EA monetary policy. A country with a tighter prudential policy setting in advance of the monetary policy shock will face smaller monetary spillovers. In this sense we find novel support for the thesis that prudential policies can help insulate countries from the global financial cycle. Importantly, we find that the size of the bank, and the size of the parent banking group, matter for this interaction.

We take advantage of our unique datasets, for France and the UK, and explore how lending made from the headquarters of a banking group differs from lending made from a financial centre, assessing how recipient-country prudential policies mediate the spillovers of EA monetary policy via cross-border bank lending. For large banking groups in France, the response of lending made from the headquarters to EA monetary policy tends to be less responsive to recipient-country prudential policies. In contrast, lending made by their affiliates located in London, a financial centre, does significantly respond to prudential policy in the final-destination country, conditional on a EA monetary policy shock.

Combining results on French and UK data, we find evidence of the presence of a 'London Bridge': French GSIBs channel funds to the UK that are then invested in third-party country depending on a prudential arbitrage. We find that French banks lending to the UK is sensitive to EA monetary policy and also to a global prudential policy cycle, reflecting the fact that the UK is an onward destination for lending. Then in the UK, we find that lending by French-owned affiliates from the UK to the rest of the world is sensitive to the financial cycle and that prudential polices in recipientcountry can offset the initial spillover.

This is not a result unique to French banks: EA banks' lending from the UK appears to be sensitive to the global financial cycle and prudential policies taken abroad seem to offset this effect. 
Table 1: Summary statistics for French banks' cross-border lending from France

\begin{tabular}{|c|c|c|c|c|c|}
\hline Variable & Mean & SD & P25 & P75 & Obs. \\
\hline \multicolumn{6}{|l|}{ Dependent variable } \\
\hline Cross-border lending growth & 0.02 & 0.36 & -0.15 & 0.19 & 90,904 \\
\hline \multicolumn{6}{|l|}{ Bank balance sheet characteristics } \\
\hline Log total assets & 16.60 & 1.75 & 15.41 & 17.68 & 103,050 \\
\hline Capital ratio & 0.07 & 0.05 & 0.04 & 0.08 & 103,050 \\
\hline Liquid assets ratio & 0.93 & 0.14 & 0.97 & 1.00 & 102,417 \\
\hline Core deposits ratio & 0.45 & 0.26 & 0.19 & 0.66 & 102,746 \\
\hline Commitments ratio & 0.09 & 0.05 & 0.06 & 0.11 & 79,020 \\
\hline International Share & 0.15 & 0.19 & 0.02 & 0.17 & 103,050 \\
\hline \multicolumn{6}{|l|}{ Lending shares } \\
\hline $\begin{array}{l}\text { Credit to the financial sector in total } \\
\text { credit }\end{array}$ & 0.60 & 0.38 & 0.20 & 0.93 & \\
\hline \multicolumn{6}{|l|}{ GSIBs } \\
\hline Log total assets & 17.25 & 2.03 & 16.05 & 19.40 & 41,582 \\
\hline International Share & 0.19 & 0.23 & 0.02 & 0.40 & 41,582 \\
\hline $\begin{array}{l}\text { Credit to the financial sector in total } \\
\text { credit }\end{array}$ & 0.64 & 0.36 & 0.34 & 0.91 & \\
\hline $\begin{array}{l}\text { Credit to the financial sector in total } \\
\text { credit to the UK }\end{array}$ & 0.67 & 0.39 & 0.22 & 0.97 & \\
\hline \multicolumn{6}{|l|}{ Non-GSIBs } \\
\hline Log total assets & 16.16 & 1.38 & 15.2 & 16.82 & 61,468 \\
\hline International Share & 0.12 & 0.15 & 0.02 & 0.13 & 61,468 \\
\hline $\begin{array}{l}\text { Credit to the financial sector in total } \\
\text { credit }\end{array}$ & 0.58 & 0.38 & 0.12 & 0.94 & \\
\hline $\begin{array}{l}\text { Credit to the financial sector in total } \\
\text { credit to the UK }\end{array}$ & 0.58 & 0.40 & 0.09 & 0.96 & \\
\hline
\end{tabular}


Table 2: Summary statistics for French-owned affiliates' cross-border lending from the UK

\begin{tabular}{|c|c|c|c|c|c|}
\hline Variable & Mean & SD & $\mathrm{P} 25$ & P75 & Obs. \\
\hline \multicolumn{6}{|l|}{ Dependent variable (French-Owned) } \\
\hline Cross-border lending growth & 0.10 & 0.50 & -0.18 & 0.22 & 10,519 \\
\hline \multicolumn{6}{|c|}{ Bank balance sheet characteristics (French-Owned) } \\
\hline Log total assets & 16.77 & 1.45 & 15.58 & 18.06 & 10,519 \\
\hline Capital ratio & 0.06 & 0.07 & 0.02 & 0.06 & 10,519 \\
\hline Liquid assets ratio & 0.52 & 0.28 & 0.27 & 0.76 & 10,519 \\
\hline Core deposits ratio & 0.13 & 0.13 & 0.05 & 0.17 & 10,519 \\
\hline Commitments ratio & 0.40 & 0.24 & 0.24 & 0.49 & 10,519 \\
\hline International Share & 0.71 & 0.16 & 0.64 & 0.83 & 10,519 \\
\hline \multicolumn{6}{|l|}{ Lending shares (French-Owned) } \\
\hline Credit to banks in total credit & 0.69 & 0.23 & $\mathrm{n} / \mathrm{a}$ & $\mathrm{n} / \mathrm{a}$ & 10,519 \\
\hline Credit to non-banks in total credit & 0.31 & 0.23 & $\mathrm{n} / \mathrm{a}$ & $\mathrm{n} / \mathrm{a}$ & 10,519 \\
\hline Loans to corporates in total loans & 0.18 & 0.18 & $\mathrm{n} / \mathrm{a}$ & $\mathrm{n} / \mathrm{a}$ & 2,333 \\
\hline Loans to households in total loans & 0.04 & 0.13 & $\mathrm{n} / \mathrm{a}$ & $\mathrm{n} / \mathrm{a}$ & 2,333 \\
\hline \multicolumn{6}{|l|}{ Lending shares (UK-owned) } \\
\hline Credit to banks in total credit & 0.46 & 0.21 & 0.34 & 0.58 & 28,097 \\
\hline Credit to non-banks in total credit & 0.54 & 0.21 & 0.42 & 0.66 & 28,205 \\
\hline Loans to corporates in total loans & 0.22 & 0.19 & 0.08 & 0.29 & 6,432 \\
\hline Loans to households in total loans & 0.09 & 0.17 & 0.00 & 0.15 & 6,453 \\
\hline \multicolumn{6}{|c|}{$\begin{array}{l}\text { Notes: Summary statistics for French-owned banks in the UK sample, spanning } 1999 \mathrm{Q} 1 \text { to } 2017 \mathrm{Q} 4.25^{\text {th }} \text { and } 75^{\text {th }} \text { percentile of lending } \\
\text { shares (P25 and P75) for French-owned banks in the UK are redacted (n/a) for reasons of confidentiality given the small number of French } \\
\text { banking groups with offices in the UK. }\end{array}$} \\
\hline
\end{tabular}


Table 3: Interactions between euro area monetary policy and recipient-country prudential policy for the cross-border lending of French banks

\begin{tabular}{|c|c|c|c|}
\hline & MP Spillover & Hybrid & Interactions \\
\hline & $(1)$ & $(2)$ & (3) \\
\hline$\Sigma_{k=0}^{0}\left(M P_{t-k}^{e a} \cdot P r u_{j, t-4}^{\text {dest }}\right)$ & & $0.110^{* *}$ & 0.060 \\
\hline$p$-value & & 0.020 & 0.187 \\
\hline$\Sigma_{k=0}^{1}\left(M P_{t-k}^{e a} \cdot P r u_{j, t-4}^{d e s t}\right)$ & & $0.221^{* * *}$ & $0.201^{* * *}$ \\
\hline$p$-value & & 0.003 & 0.006 \\
\hline$\Sigma_{k=0}^{2}\left(M P_{t-k}^{e a} \cdot P r u_{j, t-4}^{d e s t}\right)$ & & $0.264^{* * *}$ & $0.256^{* * *}$ \\
\hline$p$-value & & 0.004 & 0.003 \\
\hline$\Sigma_{k=0}^{3}\left(M P_{t-k}^{e a} \cdot P r u_{j, t-4}^{\text {dest }}\right)$ & & $0.376^{* * *}$ & $0.313^{* * *}$ \\
\hline$p$-value & & 0.000 & 0.003 \\
\hline$\Sigma_{k=0}^{0} M P_{t-k}^{e a}$ & $-0.230^{* *}$ & $-0.361^{* * *}$ & \\
\hline$p$-value & 0.016 & 0.001 & \\
\hline$\Sigma_{k=0}^{1} M P_{t-k}^{e a}$ & -0.022 & -0.201 & \\
\hline$p$-value & 0.868 & 0.254 & \\
\hline$\Sigma_{k=0}^{2} M P_{t-k}^{e a}$ & -0.180 & $-0.359^{*}$ & \\
\hline$p$-value & 0.292 & 0.095 & \\
\hline$\Sigma_{k=0}^{3} M P_{t-k}^{e a}$ & -0.045 & -0.355 & \\
\hline$p$-value & 0.836 & 0.197 & \\
\hline \multirow[t]{2}{*}{$\operatorname{Pru}_{j, t-4}^{\text {dest }}$} & & 0.000 & 0.003 \\
\hline & & $(0.002)$ & $(0.002)$ \\
\hline \multirow[t]{2}{*}{$\log (\text { Total Assets })_{t-1}$} & $-0.038^{* *}$ & $-0.041^{* *}$ & -0.031 \\
\hline & $(0.016)$ & $(0.018)$ & $(0.028)$ \\
\hline \multirow[t]{2}{*}{ Capital Ratio $_{t-1}$} & $-0.004^{*}$ & $-0.007^{*}$ & -0.006 \\
\hline & $(0.002)$ & $(0.004)$ & $(0.004)$ \\
\hline \multirow[t]{2}{*}{ Liquid Asset Ratio ${ }_{t-1}$} & 0.000 & 0.000 & 0.000 \\
\hline & $(0.001)$ & $(0.001)$ & $(0.001)$ \\
\hline \multirow[t]{2}{*}{ Core Deposits Ratio $_{t-1}$} & -0.001 & -0.000 & -0.000 \\
\hline & $(0.001)$ & $(0.002)$ & $(0.001)$ \\
\hline \multirow[t]{2}{*}{ Commitment Share $_{t-1}$} & 0.000 & -0.001 & -0.002 \\
\hline & $(0.002)$ & $(0.002)$ & $(0.002)$ \\
\hline \multirow[t]{2}{*}{ International Share $_{t-1}$} & 0.000 & 0.000 & 0.000 \\
\hline & $(0.001)$ & $(0.001)$ & $(0.001)$ \\
\hline \multirow[t]{2}{*}{ Annual GDP Growth dest $^{\text {dest }}$} & $0.005^{* * *}$ & $0.004^{* * *}$ & $0.002^{* * *}$ \\
\hline & $(0.001)$ & $(0.001)$ & $(0.001)$ \\
\hline \multirow[t]{2}{*}{ Credit to GDP Growt $h_{t-1}^{\text {dest }}$} & $0.114^{* * *}$ & $0.137^{* * *}$ & $0.133^{* * *}$ \\
\hline & $(0.024)$ & $(0.025)$ & $(0.023)$ \\
\hline \multirow[t]{2}{*}{$V I X_{t-1}$} & 0.000 & -0.000 & \\
\hline & $(0.001)$ & $(0.001)$ & \\
\hline Time FE & NO & NO & YES \\
\hline Bank FE & YES & YES & YES \\
\hline Receiving Country FE & YES & YES & YES \\
\hline Other Systemic MoPo & YES & YES & N/A \\
\hline Observations & 46,045 & 42,802 & 42,802 \\
\hline R-squared & 0.02 & 0.02 & 0.04 \\
\hline Adjusted R-squared & 0.02 & 0.02 & 0.04 \\
\hline
\end{tabular}

Notes: Dependent variable is quarterly \% change in cross-border lending, winsorised at the $10 \%$ level. Prudential policy measure is the sum of prudential policy actions (excluding reserve requirements) over a 2-year period. French sample: 2000Q12013Q2. Standard errors, in brackets, are clustered by bank and time. 
Table 4: Interactions between euro area monetary policy and recipient-country prudential policy, for French banks with a GSIB parent vs. non-GSIBs and large vs. small banks

\begin{tabular}{|c|c|c|c|c|c|c|}
\hline & \multicolumn{2}{|c|}{ All banks } & \multicolumn{2}{|c|}{ Large } & \multicolumn{2}{|c|}{ Small } \\
\hline & (1) & (2) & (3) & (4) & (5) & (6) \\
\hline & GSIB & $\begin{array}{l}\text { Non- } \\
\text { GSIB }\end{array}$ & GSIB & $\begin{array}{l}\text { Non- } \\
\text { GSIB }\end{array}$ & GSIB & $\begin{array}{l}\text { Non- } \\
\text { GSIB }\end{array}$ \\
\hline$\Sigma_{k=0}^{0}\left(M P_{t-k}^{\text {home }} \cdot P r u_{j, t-4}^{\text {dest }}\right)$ & -0.001 & $0.118^{*}$ & 0.052 & 0.086 & -0.008 & 0.120 \\
\hline$p$-value & 0.990 & 0.076 & 0.704 & 0.591 & 0.922 & 0.106 \\
\hline$\Sigma_{k=0}^{1}\left(M P_{t-k}^{\text {home }} \cdot P r u_{j, t-4}^{\text {dest }}\right)$ & 0.067 & $0.369^{* * *}$ & 0.157 & 0.040 & 0.059 & $0.450^{* * *}$ \\
\hline$p$-value & 0.502 & 0.001 & 0.462 & 0.881 & 0.606 & 0.000 \\
\hline$\Sigma_{k=0}^{2}\left(M P_{t-k}^{h o m e} \cdot P r u_{j, t-4}^{d e s t}\right)$ & 0.048 & $0.539^{* * *}$ & 0.173 & 0.233 & 0.037 & $0.613^{* * *}$ \\
\hline$p$-value & 0.692 & 0.000 & 0.446 & 0.497 & 0.797 & 0.000 \\
\hline$\Sigma_{k=0}^{3}\left(M P_{t-k}^{\text {home }} \cdot P r u_{j, t-4}^{\text {dest }}\right)$ & 0.070 & $0.641^{* * *}$ & 0.190 & 0.300 & 0.069 & $0.735^{* * *}$ \\
\hline$p$-value & 0.633 & 0.000 & 0.484 & 0.459 & 0.693 & 0.000 \\
\hline Pru $u_{j, t-4}^{d e s t}$ & 0.003 & 0.004 & -0.001 & 0.009 & 0.005 & 0.004 \\
\hline & $(0.003)$ & $(0.003)$ & $(0.006)$ & $(0.008)$ & $(0.004)$ & $(0.003)$ \\
\hline $\log (\text { Total Assets })_{t-1}$ & -0.036 & $-0.064^{* *}$ & -0.035 & 0.004 & $-0.186^{* *}$ & $-0.091^{*}$ \\
\hline & $(0.054)$ & $(0.038)$ & $(0.077)$ & $(0.124)$ & $(0.084)$ & $(0.047)$ \\
\hline Capital Ratio $_{t-1}$ & $-0.010^{* *}$ & -0.006 & -0.006 & 0.011 & $-0.021^{*}$ & -0.011 \\
\hline & $(0.004)$ & $(0.005)$ & $(0.004)$ & $(0.008)$ & $(0.012)$ & $(0.008)$ \\
\hline Liquid Asset Ratio t-1 $_{t}$ & 0.000 & 0.001 & 0.000 & 0.000 & $0.009^{* * *}$ & $-0.003^{*}$ \\
\hline & $(0.001)$ & $(0.001)$ & $(0.001)$ & $(0.002)$ & $(0.003)$ & $(0.002)$ \\
\hline Core Deposits Ratio t-1 & 0.001 & $-0.003^{*}$ & 0.001 & $0.004^{*}$ & 0.000 & $-0.004^{*}$ \\
\hline & $(0.001)$ & $(0.002)$ & $(0.001)$ & $(0.003)$ & $(0.002)$ & $(0.003)$ \\
\hline Commitment Share $_{t-1}$ & -0.002 & -0.002 & -0.002 & 0.001 & -0.004 & -0.003 \\
\hline & $(0.003)$ & $(0.003)$ & $(0.003)$ & $(0.015)$ & $(0.005)$ & $(0.003)$ \\
\hline International Share $_{t-1}$ & 0.001 & 0.000 & 0.001 & -0.001 & 0.002 & -0.001 \\
\hline & $(0.002)$ & $(0.002)$ & $(0.003)$ & $(0.002)$ & $(0.003)$ & $(0.002)$ \\
\hline Annual GDP Growth $h_{t-4}^{\text {dest }}$ & 0.001 & $0.003^{* *}$ & 0.001 & 0.003 & 0.001 & 0.002 \\
\hline & $(0.001)$ & $(0.001)$ & $(0.002)$ & $(0.003)$ & $(0.001)$ & $(0.002)$ \\
\hline Credit to GDP Growth $h_{t-1}^{\text {dest }}$ & $0.139^{* * *}$ & $0.134^{* * *}$ & $0.150^{* * *}$ & $0.140^{*}$ & $0.112^{* *}$ & $0.138^{* * *}$ \\
\hline & $(0.035)$ & $(0.032)$ & $(0.055)$ & $(0.081)$ & $(0.045)$ & $(0.036)$ \\
\hline Time FE & YES & YES & YES & YES & YES & YES \\
\hline Bank FE & YES & YES & YES & YES & YES & YES \\
\hline Receiving Country FE & YES & YES & YES & YES & YES & YES \\
\hline Observations & 19,896 & 22,906 & 6,959 & 3,894 & 12,937 & 19,012 \\
\hline R-squared & 0.06 & 0.04 & 0.02 & 0.04 & 0.10 & 0.06 \\
\hline Adjusted R-squared & 0.05 & 0.04 & 0.01 & 0.02 & 0.09 & 0.05 \\
\hline
\end{tabular}


Table 5: Interactions between euro area monetary policy and rest-of-the-world prudential policy for the lending of French banks towards the UK

\begin{tabular}{|c|c|c|}
\hline & \multicolumn{2}{|c|}{ Cross-border lending from France to the UK } \\
\hline & $(1)$ & $(2)$ \\
\hline & GSIBs & Non-GSIBs \\
\hline$\Sigma_{k=0}^{0}\left(M P_{t-k}^{E A} \cdot P r u_{j, t-4}^{R o W}\right)$ & $0.160^{* * *}$ & 0.057 \\
\hline$p$-value & 0.002 & 0.344 \\
\hline$\Sigma_{k=0}^{1}\left(M P_{t-k}^{E A} \cdot P r u_{j, t-4}^{R o W}\right)$ & $0.302^{* * *}$ & 0.094 \\
\hline$p$-value & 0.001 & 0.358 \\
\hline$\Sigma_{k=0}^{2}\left(M P_{t-k}^{E A} \cdot P r u_{j, t-4}^{R o W}\right)$ & $0.499^{* * *}$ & 0.074 \\
\hline$p$-value & 0.000 & 0.598 \\
\hline$\Sigma_{k=0}^{3}\left(M P_{t-k}^{E A} \cdot \operatorname{Pr} u_{j, t-4}^{R o W}\right)$ & $0.623^{* * *}$ & 0.084 \\
\hline$p$-value & 0.000 & 0.619 \\
\hline $\operatorname{Pru} u_{j, t-4}^{R o W}$ & 0.002 & -0.001 \\
\hline & $(0.002)$ & $(0.002)$ \\
\hline $\log (\text { Total Assets })_{t-1}$ & $-0.192^{*}$ & -0.073 \\
\hline & $(0.113)$ & $(0.070)$ \\
\hline Capital Ratio $_{t-1}$ & -0.007 & -0.015 \\
\hline & $(0.014)$ & $(0.011)$ \\
\hline${\text { Liquid Asset } \text { Ratio }_{t-1}}$ & -0.003 & $0.009^{* *}$ \\
\hline & $(0.003)$ & $(0.004)$ \\
\hline Core Deposits Ratio $_{t-1}$ & -0.004 & 0.000 \\
\hline & $(0.004)$ & $(0.003)$ \\
\hline Commitment Share $_{t-1}$ & -0.015 & -0.003 \\
\hline & $(0.009)$ & $(0.006)$ \\
\hline International Share $_{t-1}$ & -0.004 & -0.004 \\
\hline & $(0.006)$ & $(0.004)$ \\
\hline Annual GDP Growth dest & -0.003 & -0.009 \\
\hline & $(0.013)$ & $(0.017)$ \\
\hline Credit to GDP Growth dest & $-2.301^{* * *}$ & -0.997 \\
\hline & $(0.700)$ & $(0.756)$ \\
\hline Time FE & $\mathrm{NO}$ & $\mathrm{NO}$ \\
\hline Bank FE & YES & YES \\
\hline Receiving Country FE & YES & YES \\
\hline Observations & 626 & 863 \\
\hline R-squared & 0.15 & 0.08 \\
\hline Adjusted R-squared & 0.06 & 0.00 \\
\hline $\begin{array}{l}\text { Notes. Dependent variable is quarterly } \% \\
\text { Prudential policy measure is the sum of pr } \\
\text { over a 2-year period, averaged across the } \\
\text { 2000Q1-2013Q2. Standard errors, in brack } \\
\text { by GSIB and non-GSIB status. }\end{array}$ & $\begin{array}{l}\text { ange in cross-border } \\
\text { lential policy action } \\
\text { rld (excluding the e } \\
\text { s, are clustered by b }\end{array}$ & $\begin{array}{l}\text { ised at the } 10 \% \text { level. } \\
\text { rve requirements) } \\
\text { UK). FR sample: } \\
\text { nks are differentiated }\end{array}$ \\
\hline
\end{tabular}


Table 6: Interactions between euro area monetary policy and recipient-country prudential policy for the cross-border lending of affiliates in the UK

\begin{tabular}{|c|c|c|c|c|}
\hline & \multicolumn{2}{|c|}{ French-owned UK affiliates in the UK } & \multirow{2}{*}{$\begin{array}{c}\text { EA-owned UK } \\
\text { affiliates } \\
\text { (3) }\end{array}$} & \multirow{2}{*}{$\begin{array}{c}\text { UK-owned } \\
\text { banks in the } \\
\text { UK } \\
(4)\end{array}$} \\
\hline & (1) & (2) & & \\
\hline & All destinations & $\begin{array}{c}\text { Excluding vis-à-vis } \\
\text { EA }\end{array}$ & All destinations & All destinations \\
\hline$\Sigma_{k=0}^{0}\left(M P_{t-k}^{E A} \cdot \operatorname{Pru}_{j, t-4}^{d e s t}\right)$ & $0.198^{* *}$ & $0.288^{* *}$ & $0.089^{* *}$ & -0.016 \\
\hline$p$-value & 0.036 & 0.019 & 0.042 & 0.770 \\
\hline$\Sigma_{k=0}^{1}\left(M P_{t-k}^{E A} \cdot P r u_{j, t-4}^{d e s t}\right)$ & 0.202 & $0.323^{*}$ & $0.122^{*}$ & -0.04 \\
\hline$p$-value & 0.182 & 0.097 & 0.078 & 0.638 \\
\hline$\Sigma_{k=0}^{2}\left(M P_{t-k}^{E A} \cdot P r u_{j, t-4}^{d e s t}\right)$ & 0.222 & 0.377 & $0.163^{*}$ & 0.005 \\
\hline$p$-value & 0.295 & 0.167 & 0.070 & 0.962 \\
\hline$\Sigma_{k=0}^{3}\left(M P_{t-k}^{E A} \cdot P r u_{j, t-4}^{\text {dest }}\right)$ & 0.103 & 0.238 & $0.182^{*}$ & 0.044 \\
\hline$p$-value & 0.693 & 0.468 & 0.082 & 0.746 \\
\hline \multirow[t]{2}{*}{ Pru $u_{j, t-4}^{d e s t}$} & -0.003 & -0.001 & 0.001 & 0.000 \\
\hline & $(0.006)$ & $(0.007)$ & $(0.002)$ & $(0.003)$ \\
\hline \multirow[t]{2}{*}{$\log (\text { Total Assets })_{t-1}$} & $-0.026^{*}$ & -0.029 & $-0.0123^{* *}$ & $0.0325^{* *}$ \\
\hline & $(0.015)$ & $(0.023)$ & $(0.006)$ & $(0.014)$ \\
\hline \multirow[t]{2}{*}{ Capital Ratio $_{t-1}$} & -0.102 & -0.177 & -0.098 & -0.115 \\
\hline & $(0.116)$ & $(0.153)$ & $(0.061)$ & $(0.092)$ \\
\hline \multirow[t]{2}{*}{ Liquid Asset Ratio $_{t-1}$} & 0.108 & 0.136 & 0.029 & $0.094^{*}$ \\
\hline & $(0.072)$ & $(0.095)$ & $(0.021)$ & $(0.056)$ \\
\hline \multirow[t]{2}{*}{ Core Deposits Ratio ${ }_{t-1}$} & -0.089 & -0.131 & 0.026 & -0.054 \\
\hline & $(0.117)$ & $(0.163)$ & $(0.036)$ & $(0.044)$ \\
\hline \multirow[t]{2}{*}{ Commitment Share $_{t-1}$} & -0.005 & 0.008 & 0.018 & $0.100^{*}$ \\
\hline & $(0.056)$ & $(0.083)$ & $(0.018)$ & $(0.058)$ \\
\hline \multirow[t]{2}{*}{ International Share $_{t-1}$} & -0.036 & -0.005 & $-0.087^{* * *}$ & $-0.332^{* * *}$ \\
\hline & $(0.079)$ & $(0.102)$ & $(0.028)$ & $(0.070)$ \\
\hline \multirow[t]{2}{*}{ Annual GDP Growth ${ }_{t-4}^{\text {dest }}$} & 0.2423 & 0.199 & $0.288^{* * *}$ & 0.132 \\
\hline & $(0.280)$ & $(0.396)$ & $(0.102)$ & $(0.142)$ \\
\hline \multirow[t]{2}{*}{ Credit to GDP Growt $h_{t-1}^{\text {dest }}$} & 0.037 & 0.007 & $0.057^{* *}$ & $0.073^{* *}$ \\
\hline & $(0.059)$ & $(0.074)$ & $(0.023)$ & $(0.031)$ \\
\hline Time FE & YES & YES & YES & YES \\
\hline Bank FE & YES & YES & YES & YES \\
\hline Receiving Country FE & YES & YES & YES & YES \\
\hline Observations & 10,519 & 6,388 & 54,655 & 28,205 \\
\hline R-squared & 0.025 & 0.027 & 0.021 & 0.023 \\
\hline Adjusted R-squared & 0.012 & 0.007 & 0.016 & 0.017 \\
\hline
\end{tabular}




\section{References}

ACPR (2018), "Chiffres du marché français de la banque et de l'assurance"

Aghion and Kharroubi (2013), "Cyclical macroeconomic policy, financial regulation, and economic growth", BIS working paper

Altavilla, Brugnolini, Gürkaynak, Motto, and Ragusa (2019), "Measuring euro area monetary policy”, ECB Working Paper no. 2281

Andrade and Ferroni (2016), "Delphic and Odyssean monetary policy shocks: Evidence from the euro-area", Federal Reserve Bank of Chicago Working Paper

Barth, Caprio Jr. and Levine (2004), "Regulatory Arbitrage and International Bank Flows", Journal of Financial Intermediation

Batsaikhan, Kalcik and Schoenmaker (2017), "Brexit and the European financial system: mapping markets, players and jobs", Bruegel Policy Contribution

Berrospide, Correa, Goldberg, and Niepmann (2017), "International Banking and Cross-Border Effects of Regulation: Lessons from the United States", International Journal of Central Banking

BIS (2010), "An assessment of the long-term economic impact of stronger capital and liquidity requirements", https://www.bis.org/publ/bcbs173.htm

Bremus and Fratzscher (2015), "Drivers of structural change in cross-border banking since the global financial crisis", Journal of International Money and Finance

Bruno and Shin (2014), “Assessing Macroprudential Policies: Case of South Korea”, Scandinavian Journal of Economics

Bruno and Shin, (2015a), "Cross-Border Banking and Global Liquidity", Review of Economic Studies

Bruno and Shin (2015b), "Capital flows and the risk-taking channel of monetary policy", Journal of Monetary Economics

Buch, Bussière, Goldberg, and Hills (2019), "The international transmission of monetary policy", Journal of International Money and Finance

Buch and Goldberg (2017), "Cross-border prudential policy spillovers: How much? How important? Evidence from the International Banking Research Network", International Journal of Central Banking

Carney (2019), "Push, pull, pipes: sustainable capital flows for a new world order," Speech at 2019 Institute of International Finance Spring Membership Meeting, Tokyo, June 6. 
Cerutti, Correa, Fiorentino and Segalla (2017), "Changes in Prudential Policy Instruments-A New Cross-Country Database", International Journal of Central Banking

Coman and Lloyd (2019), "In the Face of Spillovers: Prudential Policies in Emerging Economies," Bank of England Staff Working Paper No. 828.

Claessens, Ghosh and Mihet (2013), "Macro-prudential policies to mitigate financial system vulnerabilities," Journal of International Money and Finance, 39: 153-185.

de Jonghe, Dewachter and Ongena (2016), "Bank capital (requirements) and credit supply: Evidence from pillar 2 decisions," Working Paper Research 303, National Bank of Belgium.

de Marco and Wieladek (2016), "The real effects of capital requirements and monetary policy: Evidence from the United Kingdom”, CEPR discussion paper.

Forbes, Reinhardt and Wieladek (2017), "The spillovers, interactions, and (un)intended consequences of monetary and regulatory policies", Journal of Monetary Economics

Gehrig, 2000, Cities and the Geography of Financial Centres in Huriot, Jean-Marie and Thisse, Jacques-François eds. Economies of Cities: Theoretical Perspectives. Cambridge: Cambridge University Press.

Gerko and Rey (2017), "Monetary Policy in the Capitals of Capital", Journal of the European Economic Association, 15(4), 721-745.

Gürkaynak, Sack, and Swanson (2005), "Do Actions Speak Louder Than Words? The Response of Asset Prices to Monetary Policy Actions and Statements", International Journal of Central Banking Houston, Lin and Ma (2012), "Regulatory Arbitrage and International Bank Flows", Journal of Finance

IMF (2011), "Macroprudential Policy: What Instruments and How to Use them? Lessons From Country Experiences," IMF Working Papers

IMF (2012), "Credit Growth and the Effectiveness of Reserve Requirements and Other Macroprudential Instruments in Latin America," IMF Working Papers

IMF (2013), “The interaction of monetary and macroprudential policies”, IMF Board Paper

Kashyap and Stein (2000), "What do a million observations on banks say about the transmission of monetary policy?" American Economic Review

Kaya, Schildbach, and Lakhani (2018), "Brexit impact on investment banking in Europe”, Deutsche Bank Research Paper

Kindleberger (1974) The Formation of Financial Centers: A Study in Comparative Economic History. Princeton University Press, New Jersey. 
Kuttner (2001), "Monetary policy surprises and interest rates: evidence from the Fed funds futures markets," Journal of Monetary Economics

Kuttner and Shim (2016), "Can non-interest rate policies stabilize housing markets? Evidence from a panel of 57 economies", Journal of Financial Stability

Montoro and Moreno (2011), "The use of reserve requirements as a policy instrument in Latin America," BIS Quarterly Review

Reinhardt and Sowerbutts (2015), "Regulatory arbitrage in action: evidence from banking flows and macroprudential policy,” Bank of England Working Paper 546.

Rey (2013), "Dilemma not Trilemma: The Global Financial Cycle and Monetary Policy Independence", Federal Reserve Bank of Kansas City Economic Symposium

Sapir, Schoenmaker, and Véron (2017), "Making the best of Brexit for the EU27 financial system", Bruegel Policy Contribution

Takats and Temesvary (2017), "Can Macroprudential Measures Make Cross-Border Lending More Resilient? Lessons from the Taper Tantrum," Finance and Economics Discussion Series 2017-123, Board of Governors of the Federal Reserve System (US).

Unsal (2011), "Capital flows and financial stability: Monetary policy and macroprudential responses", IMF Working Paper 


\section{Appendix - Not for Publication}

In this Appendix, we present additional plots and the results of additional robustness exercises to complement our benchmark results in the main body of the paper.

Figure A: Time series variation in cumulated aggregate prudential policy actions, excluding reserve requirements, for selected countries, 2001Q4-2017Q4

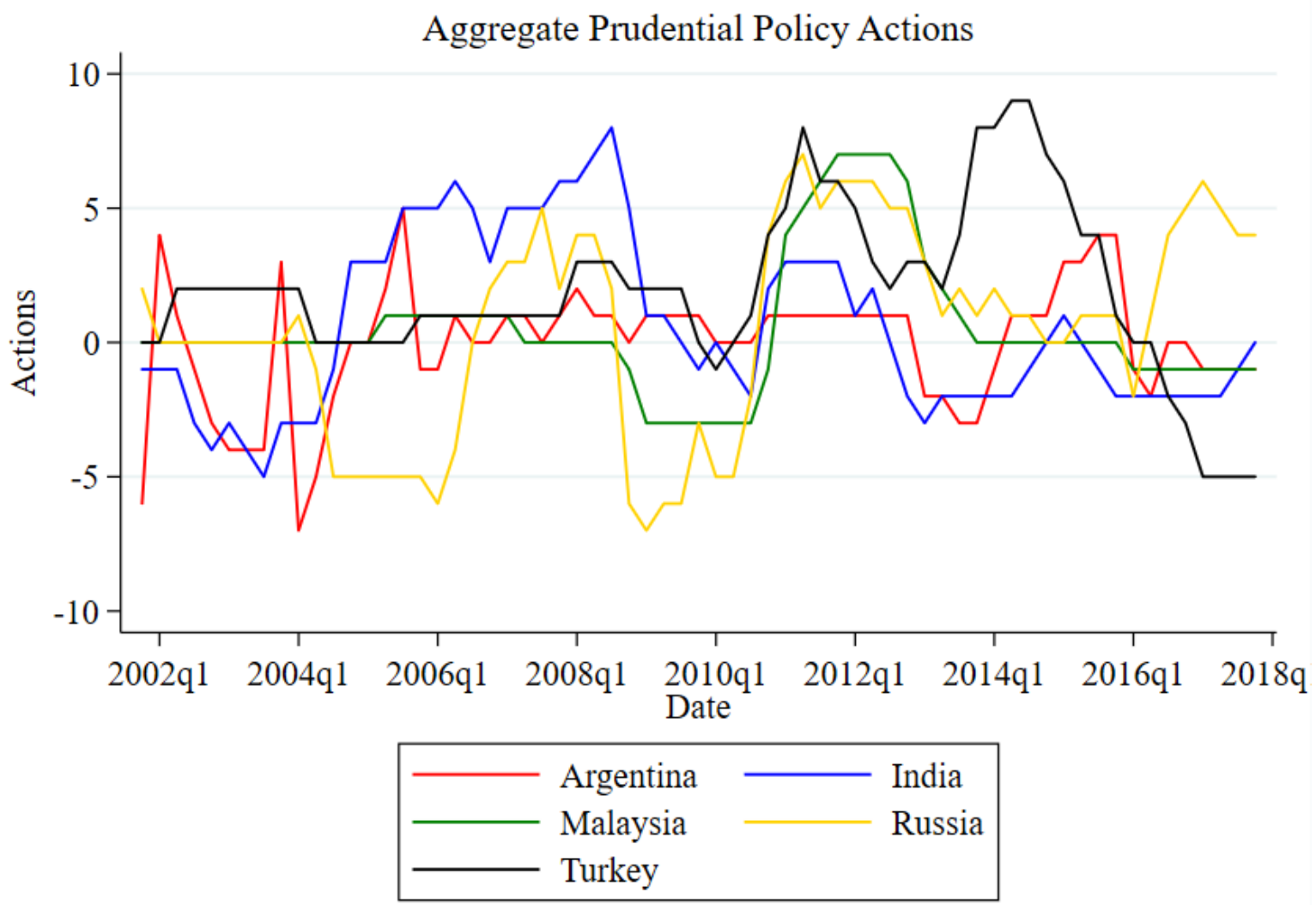

Notes: Time series of two-year cumulated aggregate prudential policy actions, constructed using all prudential policies, except reserve requirements, in the Cerutti et al. (2017b) prudential policy actions dataset between 2001:Q4 and 2017:Q4 in selected countries.

Table A: Summary Statistics for Cumulated Prudential Policy Measure

\begin{tabular}{|l|c|c|c|c|c|}
\hline Sample & \# Obs. & Mean & Std. Dev. & Min. & Max. \\
\hline 2001Q4-2013Q2 & 3008 & 0.294 & 0.920 & -3 & 6 \\
\hline 2001Q4-2017Q4 & 4160 & 0.397 & 1.054 & -3 & 6 \\
\hline
\end{tabular}

Notes: Statistics constructed by pooling observations across the 64 countries in the Cerutti et al. (2017) dataset over the two sample periods. The samples begin in 2001Q4 to reflect the two-year cumulation of policy actions. The 2013Q2 represents the end date of the benchmark French sample, and 2017Q4 the corresponding end date for the benchmark UK sample. 
Table A3a: Interactions between euro area monetary policy and recipient-country prudential policy for the cross-border lending of French banks using alternative EA monetary policy series from Andrade and Ferroni (2016)

\begin{tabular}{|c|c|c|c|}
\hline & MP Spillover & Hybrid & Interactions \\
\hline & (1) & (2) & (3) \\
\hline$\Sigma_{k=0}^{0}\left(M P_{t-k}^{e a} \cdot P r u_{j, t-4}^{\text {dest }}\right)$ & & $0.163^{* * *}$ & $0.083^{*}$ \\
\hline$p$-value & & 0.001 & 0.083 \\
\hline$\Sigma_{k=0}^{1}\left(M P_{t-k}^{e a} \cdot \operatorname{Pr} u_{j, t-4}^{d e s t}\right)$ & & $0.282^{* * *}$ & $0.228^{* * *}$ \\
\hline$p$-value & & 0.000 & 0.002 \\
\hline$\Sigma_{k=0}^{2}\left(M P_{t-k}^{e a} \cdot P r u_{j, t-4}^{d e s t}\right)$ & & $0.334^{* * *}$ & $0.310^{* * *}$ \\
\hline$p$-value & & 0.000 & 0.000 \\
\hline$\Sigma_{k=0}^{3}\left(M P_{t-k}^{e a} \cdot P r u_{j, t-4}^{\text {dest }}\right)$ & & $0.476^{* * *}$ & $0.385^{* * *}$ \\
\hline$p$-value & & 0.000 & 0.000 \\
\hline$\Sigma_{k=0}^{0} M P_{t-k}^{e a}$ & $-0.452^{* * *}$ & $-0.483^{* * *}$ & \\
\hline$p$-value & 0.000 & 0.000 & \\
\hline$\Sigma_{k=0}^{1} M P_{t-k}^{e a}$ & -0.197 & -0.247 & \\
\hline$p$-value & 0.333 & 0.231 & \\
\hline$\Sigma_{k=0}^{2} M P_{t-k}^{e a}$ & -0.222 & -0.275 & \\
\hline$p$-value & 0.370 & 0.271 & \\
\hline$\Sigma_{k=0}^{3} M P_{t-k}^{e a}$ & -0.124 & -0.219 & \\
\hline$p$-value & 0.702 & 0.502 & \\
\hline \multirow[t]{2}{*}{$\operatorname{Pru}_{j, t-4}^{\text {dest }}$} & & $-0.006^{* *}$ & \\
\hline & & $(0.002)$ & \\
\hline \multirow[t]{2}{*}{$\log (\text { Total Assets })_{t-1}$} & $-0.039^{* *}$ & $-0.037^{* *}$ & -0.031 \\
\hline & $(0.018)$ & $(0.018)$ & $(0.028)$ \\
\hline \multirow[t]{2}{*}{ Capital Ratio $_{t-1}$} & $-0.006^{*}$ & $-0.007^{*}$ & -0.006 \\
\hline & $(0.004)$ & $(0.004)$ & $(0.004)$ \\
\hline \multirow[t]{2}{*}{ Liquid Asset Ratio $_{t-1}$} & 0.001 & 0.001 & 0.000 \\
\hline & $(0.001)$ & $(0.001)$ & $(0.001)$ \\
\hline \multirow[t]{2}{*}{ Core Deposits Ratio $_{t-1}$} & -0.000 & -0.000 & -0.000 \\
\hline & $(0.001)$ & $(0.001)$ & $(0.001)$ \\
\hline \multirow[t]{2}{*}{ Commitment Share $_{t-1}$} & -0.001 & -0.001 & -0.002 \\
\hline & $(0.002)$ & $(0.002)$ & $(0.002)$ \\
\hline \multirow[t]{2}{*}{ International Share $_{t-1}$} & 0.000 & 0.000 & -0.000 \\
\hline & $(0.001)$ & $(0.001)$ & $(0.001)$ \\
\hline \multirow[t]{2}{*}{ Annual GDP Growth ${ }_{t-4}^{\text {dest }}$} & $0.004^{* * *}$ & $0.004^{* * *}$ & $0.002^{* * *}$ \\
\hline & $(0.001)$ & $(0.001)$ & $(0.001)$ \\
\hline \multirow[t]{2}{*}{ Credit to GDP Growth ${ }_{t-1}^{\text {dest }}$} & $0.132^{* * *}$ & $0.142^{* * *}$ & $0.134^{* * *}$ \\
\hline & $(0.024)$ & $(0.025)$ & $(0.023)$ \\
\hline \multirow[t]{2}{*}{$V I X_{t-1}$} & -0.000 & -0.000 & \\
\hline & $(0.001)$ & $(0.001)$ & \\
\hline Time FE & $\mathrm{NO}$ & $\mathrm{NO}$ & YES \\
\hline Bank FE & YES & YES & YES \\
\hline Receiving Country FE & YES & YES & YES \\
\hline Observations & 42,802 & 42,802 & 42,802 \\
\hline R-squared & 0.02 & 0.02 & 0.04 \\
\hline Adjusted R-squared & 0.02 & 0.02 & 0.04 \\
\hline
\end{tabular}

Notes: Dependent variable is quarterly \% change in cross-border lending, winsorised at the $10 \%$ level. Prudential policy measure is the sum of prudential policy actions (excluding reserve requirements) over a 2-year period. French sample: 2000Q12013Q2. Standard errors, in brackets, are clustered by bank and time. 
Table A3b: Interactions between euro area monetary policy and recipient-country prudential policy for the cross-border lending of French banks using different cumulation for the prudential index (5 years vs. 2 years in baseline regressions)

\begin{tabular}{|c|c|c|c|}
\hline & MP Spillover & Hybrid & Interactions \\
\hline & $(1)$ & $(2)$ & (3) \\
\hline$\Sigma_{k=0}^{0}\left(M P_{t-k}^{e a} \cdot P r u_{j, t-1}^{\text {dest }}\right)$ & & $0.052^{* *}$ & 0.010 \\
\hline$p$-value & & 0.048 & 0.696 \\
\hline$\Sigma_{k=0}^{1}\left(M P_{t-k}^{e a} \cdot \operatorname{Pr} u_{j, t-1}^{d e s t}\right)$ & & $0.218^{* * *}$ & $0.151^{* * *}$ \\
\hline$p$-value & & 0.000 & 0.002 \\
\hline$\Sigma_{k=0}^{2}\left(M P_{t-k}^{e a} \cdot P r u_{j, t-1}^{d e s t}\right)$ & & $0.215^{* * *}$ & $0.172^{* * *}$ \\
\hline$p$-value & & 0.000 & 0.000 \\
\hline$\Sigma_{k=0}^{3}\left(M P_{t-k}^{e a} \cdot P r u_{j, t-1}^{\text {dest }}\right)$ & & $0.311^{* * *}$ & $0.224^{* * *}$ \\
\hline$p$-value & & 0.000 & 0.000 \\
\hline$\Sigma_{k=0}^{0} M P_{t-k}^{e a}$ & $-0.230^{* * *}$ & $-0.382^{* * *}$ & \\
\hline$p$-value & 0.016 & 0.000 & \\
\hline$\Sigma_{k=0}^{1} M P_{t-k}^{e a}$ & -0.022 & $-0.322^{*}$ & \\
\hline$p$-value & 0.868 & 0.070 & \\
\hline$\Sigma_{k=0}^{2} M P_{t-k}^{e a}$ & -0.180 & $-0.359^{*}$ & \\
\hline$p$-value & 0.292 & 0.082 & \\
\hline$\Sigma_{k=0}^{3} M P_{t-k}^{e a}$ & -0.045 & -0.347 & \\
\hline$p$-value & 0.836 & 0.160 & \\
\hline \multirow[t]{2}{*}{$\operatorname{Pru}_{j, t-1}^{\text {dest }}$} & & $0.003^{*}$ & \\
\hline & & $(0.002)$ & \\
\hline \multirow[t]{2}{*}{$\log (\text { Total Assets })_{t-1}$} & $-0.038^{* *}$ & $-0.036^{* *}$ & -0.027 \\
\hline & $(0.016)$ & $(0.017)$ & $(0.026)$ \\
\hline \multirow[t]{2}{*}{ Capital Ratio $_{t-1}$} & $-0.004^{*}$ & $-0.006^{*}$ & -0.005 \\
\hline & $(0.002)$ & $(0.003)$ & $(0.003)$ \\
\hline \multirow[t]{2}{*}{ Liquid Asset Ratio $_{t-1}$} & 0.000 & 0.000 & 0.000 \\
\hline & $(0.001)$ & $(0.001)$ & $(0.001)$ \\
\hline \multirow[t]{2}{*}{ Core Deposits Ratio $_{t-1}$} & -0.001 & -0.000 & -0.000 \\
\hline & $(0.001)$ & $(0.001)$ & $(0.001)$ \\
\hline \multirow[t]{2}{*}{ Commitment Share $_{t-1}$} & 0.000 & -0.000 & -0.001 \\
\hline & $(0.002)$ & $(0.002)$ & $(0.002)$ \\
\hline \multirow[t]{2}{*}{ International Share $_{t-1}$} & 0.000 & 0.000 & -0.000 \\
\hline & $(0.001)$ & $(0.001)$ & $(0.001)$ \\
\hline \multirow[t]{2}{*}{ Annual GDP Growth $h_{t-4}^{\text {dest }}$} & $0.005^{* * *}$ & $0.004^{* * *}$ & $0.003^{* * *}$ \\
\hline & $(0.001)$ & $(0.001)$ & $(0.001)$ \\
\hline \multirow[t]{2}{*}{ Credit to GDP Growth ${ }_{t-1}^{d e s t}$} & $0.114^{* * *}$ & $0.119^{* * *}$ & $0.105^{* * *}$ \\
\hline & $(0.024)$ & $(0.025)$ & $(0.022)$ \\
\hline \multirow[t]{2}{*}{$V I X_{t-1}$} & 0.000 & 0.000 & \\
\hline & $(0.001)$ & $(0.001)$ & \\
\hline Time FE & $\mathrm{NO}$ & $\mathrm{NO}$ & YES \\
\hline Bank FE & YES & YES & YES \\
\hline Receiving Country FE & YES & YES & YES \\
\hline Observations & 42,802 & 42,802 & 42,802 \\
\hline R-squared & 0.02 & 0.02 & 0.04 \\
\hline Adjusted R-squared & 0.02 & 0.02 & 0.04 \\
\hline
\end{tabular}

Notes: Dependent variable is quarterly \% change in cross-border lending, winsorised at the $10 \%$ level. Prudential policy measure is the sum of prudential policy actions (excluding reserve requirements) over a 2-year period. French sample: 2000Q12013Q2. Standard errors, in brackets, are clustered by bank and time. 
Table A4a: Interactions between euro area monetary policy and recipient-country prudential policy, for French banks with a GSIB parent vs. non-GSIBs and large vs. small banks using alternative EA monetary policy series from Andrade and Ferroni (2016)

\begin{tabular}{|c|c|c|c|c|c|c|}
\hline & \multicolumn{2}{|c|}{ All banks } & \multicolumn{2}{|c|}{ Large } & \multicolumn{2}{|c|}{ Small } \\
\hline & (1) & (2) & (3) & (4) & (5) & (6) \\
\hline & GSIB & $\begin{array}{l}\text { Non- } \\
\text { GSIB }\end{array}$ & GSIB & $\begin{array}{l}\text { Non- } \\
\text { GSIB }\end{array}$ & GSIB & $\begin{array}{l}\text { Non- } \\
\text { GSIB }\end{array}$ \\
\hline$\Sigma_{k=0}^{0}\left(M P_{t-k}^{h o m e} \cdot P r u_{j, t-4}^{d e s t}\right)$ & -0.016 & $0.162^{* *}$ & 0.017 & 0.076 & -0.007 & $0.184^{* *}$ \\
\hline$p^{\text {-value }}$ & 0.820 & 0.026 & 0.905 & 0.648 & 0.933 & 0.026 \\
\hline$\Sigma_{k=0}^{1}\left(M P_{t-k}^{\text {home }} \cdot P r u_{j, t-4}^{\text {dest }}\right)$ & 0.041 & $0.420^{* * *}$ & 0.095 & -0.001 & 0.058 & $0.540^{* * *}$ \\
\hline$p$-value & 0.691 & 0.000 & 0.658 & 0.997 & 0.641 & 0.000 \\
\hline$\Sigma_{k=0}^{2}\left(M P_{t-k}^{h o m e} \cdot P r u_{j, t-4}^{\text {dest }}\right)$ & 0.041 & $0.585^{* * *}$ & 0.097 & 0.160 & 0.069 & $0.705^{* * *}$ \\
\hline$p$-value & 0.750 & 0.000 & 0.670 & 0.557 & 0.667 & 0.000 \\
\hline$\Sigma_{k=0}^{3}\left(M P_{t-k}^{h o m e} \cdot P r u_{j, t-4}^{d e s t}\right)$ & 0.084 & $0.670^{* * *}$ & 0.130 & 0.201 & 0.123 & $0.820^{* * *}$ \\
\hline$p$-value & 0.580 & 0.000 & 0.624 & 0.549 & 0.519 & 0.000 \\
\hline$P r u_{j, t-4}^{d e s t}$ & 0.003 & -0.001 & -0.002 & 0.006 & 0.005 & -0.002 \\
\hline & $(0.003)$ & $(0.003)$ & $(0.005)$ & $(0.007)$ & $(0.004)$ & $(0.003)$ \\
\hline $\log (\text { Total Assets })_{t-1}$ & -0.036 & $-0.064^{* *}$ & -0.035 & 0.004 & $-0.186^{* *}$ & $-0.091^{*}$ \\
\hline & $(0.054)$ & $(0.038)$ & $(0.077)$ & $(0.124)$ & $(0.084)$ & $(0.047)$ \\
\hline Capital Ratio $_{t-1}$ & $-0.010^{* *}$ & -0.006 & -0.006 & 0.011 & $-0.021^{*}$ & -0.011 \\
\hline & $(0.004)$ & $(0.005)$ & $(0.004)$ & $(0.008)$ & $(0.012)$ & $(0.008)$ \\
\hline${\text { Liquid Asset } \text { Ratio }_{t-1}}$ & 0.000 & 0.001 & 0.000 & 0.000 & $0.009^{* * *}$ & $-0.003^{*}$ \\
\hline & $(0.001)$ & $(0.001)$ & $(0.001)$ & $(0.002)$ & $(0.003)$ & $(0.002)$ \\
\hline 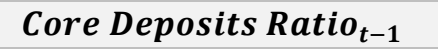 & 0.001 & $-0.003^{*}$ & 0.001 & $0.004^{*}$ & 0.000 & $-0.004^{*}$ \\
\hline & $(0.001)$ & $(0.002)$ & $(0.001)$ & $(0.003)$ & $(0.002)$ & $(0.002)$ \\
\hline Commitment Share St-1 $_{t}$ & -0.002 & -0.002 & -0.002 & 0.000 & -0.004 & -0.003 \\
\hline & $(0.003)$ & $(0.003)$ & $(0.003)$ & $(0.015)$ & $(0.004)$ & $(0.003)$ \\
\hline International Share $_{t-1}$ & 0.001 & 0.000 & 0.001 & -0.001 & 0.002 & -0.001 \\
\hline & $(0.002)$ & $(0.002)$ & $(0.003)$ & $(0.002)$ & $(0.003)$ & $(0.002)$ \\
\hline Annual GDP Growth $h_{t-4}^{\text {dest }}$ & 0.001 & $0.003^{* *}$ & 0.001 & 0.003 & 0.001 & 0.002 \\
\hline & $(0.001)$ & $(0.001)$ & $(0.002)$ & $(0.003)$ & $(0.001)$ & $(0.002)$ \\
\hline Credit to GDP Growth dest $^{\text {dest }}$ & $0.140^{* * *}$ & $0.133^{* * *}$ & $0.149^{* * *}$ & $0.138^{*}$ & $0.113^{* *}$ & $0.137^{* * *}$ \\
\hline & $(0.035)$ & $(0.032)$ & $(0.055)$ & $(0.081)$ & $(0.045)$ & $(0.035)$ \\
\hline Time FE & YES & YES & YES & YES & YES & YES \\
\hline Bank FE & YES & YES & YES & YES & YES & YES \\
\hline Receiving Country FE & YES & YES & YES & YES & YES & YES \\
\hline Observations & 19,896 & 22,906 & 6,959 & 3,894 & 12,937 & 19,012 \\
\hline R-squared & 0.06 & 0.04 & 0.02 & 0.04 & 0.10 & 0.06 \\
\hline Adjusted R-squared & 0.05 & 0.04 & 0.01 & 0.02 & 0.09 & 0.05 \\
\hline
\end{tabular}


Table A4b: Interactions between euro area monetary policy and recipient-country prudential policy, for French banks with a GSIB parent vs. non-GSIBs and large vs. small banks using different cumulation for the prudential index (5 years vs. 2 years in baseline regressions)

\begin{tabular}{|c|c|c|c|c|c|c|}
\hline & \multicolumn{2}{|c|}{ All banks } & \multicolumn{2}{|c|}{ Large } & \multicolumn{2}{|c|}{ Small } \\
\hline & (1) & (2) & (3) & (4) & (5) & (6) \\
\hline & GSIB & $\begin{array}{l}\text { Non- } \\
\text { GSIB }\end{array}$ & GSIB & $\begin{array}{l}\text { Non- } \\
\text { GSIB }\end{array}$ & GSIB & $\begin{array}{l}\text { Non- } \\
\text { GSIB }\end{array}$ \\
\hline$\Sigma_{k=0}^{0}\left(M P_{t-k}^{\text {home }} \cdot P r u_{j, t-1}^{\text {dest }}\right)$ & 0.003 & 0.023 & 0.078 & 0.024 & -0.025 & 0.016 \\
\hline$p$-value & 0.944 & 0.538 & 0.333 & 0.751 & 0.537 & 0.706 \\
\hline$\Sigma_{k=0}^{1}\left(M P_{t-k}^{h o m e} \cdot \operatorname{Pru}_{j, t-1}^{\text {dest }}\right)$ & 0.084 & $0.234^{* * *}$ & 0.157 & 0.039 & 0.063 & $0.277^{* * *}$ \\
\hline$p$-value & 0.154 & 0.000 & 0.196 & 0.790 & 0.345 & 0.000 \\
\hline$\Sigma_{k=0}^{2}\left(M P_{t-k}^{h o m e} \cdot \operatorname{Pru}_{j, t-1}^{\text {dest }}\right)$ & 0.096 & $0.259^{* * *}$ & 0.214 & 0.118 & 0.061 & $0.288^{* * *}$ \\
\hline$p$-value & 0.237 & 0.000 & 0.117 & 0.555 & 0.537 & 0.000 \\
\hline$\Sigma_{k=0}^{3}\left(M P_{t-k}^{h o m e} \cdot P r u_{j, t-1}^{d e s t}\right)$ & 0.131 & $0.321^{* * *}$ & 0.143 & 0.119 & 0.144 & $0.377^{* * *}$ \\
\hline$p$-value & 0.196 & 0.000 & 0.386 & 0.611 & 0.260 & 0.000 \\
\hline \multirow[t]{2}{*}{$\operatorname{Pr} u_{j, t-1}^{d e s t}$} & $0.007^{* * *}$ & $0.005^{* *}$ & 0.003 & 0.007 & $0.009^{* * *}$ & $0.005^{* *}$ \\
\hline & $(0.002)$ & $(0.002)$ & $(0.004)$ & $(0.006)$ & $(0.003)$ & $(0.002)$ \\
\hline \multirow[t]{2}{*}{$\log (\text { Total Assets })_{t-1}$} & -0.041 & -0.058 & -0.078 & 0.003 & $-0.178^{* *}$ & $-0.083^{*}$ \\
\hline & $(0.050)$ & $(0.037)$ & $(0.066)$ & $(0.124)$ & $(0.084)$ & $(0.046)$ \\
\hline \multirow[t]{2}{*}{ Capital Ratio $_{t-1}$} & $-0.009^{* *}$ & -0.006 & $-0.008^{*}$ & 0.011 & $-0.021^{*}$ & -0.011 \\
\hline & $(0.004)$ & $(0.005)$ & $(0.004)$ & $(0.008)$ & $(0.012)$ & $(0.007)$ \\
\hline \multirow[t]{2}{*}{ Liquid Asset Ratio $_{t-1}$} & 0.000 & 0.000 & 0.000 & 0.000 & $0.008^{* * *}$ & -0.002 \\
\hline & $(0.001)$ & $(0.001)$ & $(0.001)$ & $(0.002)$ & $(0.003)$ & $(0.001)$ \\
\hline \multirow[t]{2}{*}{${\text { Core Deposits } \text { Ratio }_{t-1}}$} & 0.001 & $-0.003^{*}$ & 0.001 & $0.004^{*}$ & 0.001 & $-0.004^{* *}$ \\
\hline & $(0.001)$ & $(0.002)$ & $(0.001)$ & $(0.003)$ & $(0.002)$ & $(0.002)$ \\
\hline \multirow[t]{2}{*}{ Commitment Share $_{t-1}$} & -0.001 & -0.002 & -0.002 & 0.000 & -0.004 & -0.002 \\
\hline & $(0.003)$ & $(0.003)$ & $(0.002)$ & $(0.015)$ & $(0.004)$ & $(0.003)$ \\
\hline \multirow[t]{2}{*}{ International Share $_{t-1}$} & 0.001 & 0.000 & 0.001 & -0.001 & 0.002 & -0.001 \\
\hline & $(0.002)$ & $(0.002)$ & $(0.002)$ & $(0.002)$ & $(0.003)$ & $(0.002)$ \\
\hline \multirow[t]{2}{*}{ Annual GDP Growth $h_{t-4}^{\text {dest }}$} & 0.001 & $0.003^{* * *}$ & 0.002 & 0.004 & 0.001 & $0.003^{*}$ \\
\hline & $(0.001)$ & $(0.001)$ & $(0.002)$ & $(0.003)$ & $(0.001)$ & $(0.001)$ \\
\hline \multirow[t]{2}{*}{ Credit to GDP Growth $h_{t-1}^{\text {dest }}$} & $0.114^{* * *}$ & $0.102^{* * *}$ & $0.122^{* * *}$ & 0.106 & $0.088^{* *}$ & $0.105^{* * *}$ \\
\hline & $(0.033)$ & $(0.032)$ & $(0.051)$ & $(0.084)$ & $(0.044)$ & $(0.034)$ \\
\hline Time FE & YES & YES & YES & YES & YES & YES \\
\hline Bank FE & YES & YES & YES & YES & YES & YES \\
\hline Receiving Country FE & YES & YES & YES & YES & YES & YES \\
\hline Observations & 19,896 & 22,906 & 6,959 & 3,894 & 12,937 & 19,012 \\
\hline R-squared & 0.06 & 0.04 & 0.02 & 0.04 & 0.10 & 0.06 \\
\hline Adjusted R-squared & 0.05 & 0.04 & 0.01 & 0.02 & 0.09 & 0.05 \\
\hline \multicolumn{7}{|c|}{$\begin{array}{l}\text { Notes: Dependent variable is quarterly \% change in cross-border lending, winsorised at the } 10 \% \text { level. Prudential policy measure is } \\
\text { the sum of prudential policy actions (excluding reserve requirements) over a 2-year period. FR sample: 2000Q1-2013Q2. Standard } \\
\text { errors, in brackets, are clustered by bank and time. Banks are differentiated by GSIB and non-GSIB status. }\end{array}$} \\
\hline
\end{tabular}


Table A5a: Interactions between euro area monetary policy and rest-of-the-world prudential policy for the lending of French banks towards the UK using different cumulation for the prudential index (5 years vs. 2 years in baseline regressions)

\begin{tabular}{|c|c|c|}
\hline & \multicolumn{2}{|c|}{ Cross-border lending from France to the UK } \\
\hline & $(1)$ & $(2)$ \\
\hline & GSIBs & Non-GSIBs \\
\hline$\Sigma_{k=0}^{0}\left(M P_{t-k}^{E A} \cdot P r u_{j, t-4}^{R o W}\right)$ & $0.072^{* * *}$ & $0.048^{*}$ \\
\hline$p$-value & 0.001 & 0.094 \\
\hline$\Sigma_{k=0}^{1}\left(M P_{t-k}^{E A} \cdot P r u_{j, t-4}^{R o W}\right)$ & $0.222^{* * *}$ & $0.125^{*}$ \\
\hline$p$-value & 0.000 & 0.066 \\
\hline$\Sigma_{k=0}^{2}\left(M P_{t-k}^{E A} \cdot P r u_{j, t-4}^{R o W}\right)$ & $0.406^{* * *}$ & 0.141 \\
\hline$p$-value & 0.000 & 0.136 \\
\hline$\Sigma_{k=0}^{3}\left(M P_{t-k}^{E A} \cdot P r u_{j, t-4}^{R o W}\right)$ & $0.533^{* * *}$ & 0.181 \\
\hline$p$-value & 0.000 & 0.139 \\
\hline $\operatorname{Pru} u_{j, t-4}^{\text {dest or } R o W}$ & 0.002 & 0.001 \\
\hline & $(0.001)$ & $(0.002)$ \\
\hline $\log (\text { Total Assets })_{t-1}$ & $-0.187^{*}$ & -0.087 \\
\hline & $(0.110)$ & $(0.070)$ \\
\hline Capital Ratio $_{t-1}$ & -0.009 & -0.015 \\
\hline & $(0.014)$ & $(0.011)$ \\
\hline Liquid Asset Ratio $_{t-1}$ & -0.002 & $0.009^{* *}$ \\
\hline & $(0.003)$ & $(0.004)$ \\
\hline Core Deposits Ratio $_{t-1}$ & -0.004 & 0.001 \\
\hline & $(0.004)$ & $(0.003)$ \\
\hline Commitment Share $_{t-1}$ & -0.014 & -0.003 \\
\hline & $(0.009)$ & $(0.006)$ \\
\hline International Share $_{t-1}$ & -0.004 & -0.004 \\
\hline & $(0.006)$ & $(0.004)$ \\
\hline Annual GDP Growth dest & -0.009 & -0.007 \\
\hline & $(0.013)$ & $(0.017)$ \\
\hline Credit to GDP Growth dest & $-2.365^{* * *}$ & -1.057 \\
\hline & $(0.689)$ & $(0.826)$ \\
\hline Time FE & $\mathrm{NO}$ & $\mathrm{NO}$ \\
\hline Bank FE & YES & YES \\
\hline Receiving Country FE & YES & YES \\
\hline Observations & 626 & 863 \\
\hline R-squared & 0.15 & 0.08 \\
\hline Adjusted R-squared & 0.06 & 0.00 \\
\hline $\begin{array}{l}\text { Notes. Dependent variable is quarterly } \% \\
\text { Prudential policy measure is the sum of pr } \\
\text { over a 2-year period, averaged across the } \\
2000 \text { Q1-2013Q2. Standard errors, in brack } \\
\text { by GSIB and non-GSIB status. }\end{array}$ & $\begin{array}{l}\text { ange in cross-borde } \\
\text { lential policy action } \\
\text { rld (excluding the e } \\
\text { s, are clustered by b }\end{array}$ & $\begin{array}{l}\text { ised at the } 10 \% \text { level. } \\
\text { rve requirements) } \\
\text { UK). FR sample: } \\
\text { anks are differentiated }\end{array}$ \\
\hline
\end{tabular}


Table A5b: Interactions between euro area monetary policy and rest-of-the-world prudential policy for the lending of French banks towards the UK using alternative EA monetary policy series from Andrade and Ferroni (2016)

\begin{tabular}{|c|c|c|}
\hline & \multicolumn{2}{|c|}{ Cross-border lending from France to the UK } \\
\hline & $(1)$ & $(2)$ \\
\hline & GSIBs & Non-GSIBs \\
\hline$\Sigma_{k=0}^{0}\left(M P_{t-k}^{E A} \cdot \operatorname{Pr} u_{j, t-1}^{R o W}\right)$ & $0.320^{* * *}$ & 0.103 \\
\hline$p^{\text {-value }}$ & 0.000 & 0.210 \\
\hline$\Sigma_{k=0}^{1}\left(M P_{t-k}^{E A} \cdot P r u_{j, t-1}^{R o W}\right)$ & $0.607^{* * *}$ & 0.193 \\
\hline$p$-value & 0.000 & 0.217 \\
\hline$\Sigma_{k=0}^{2}\left(M P_{t-k}^{E A} \cdot \operatorname{Pr} u_{j, t-1}^{R o W}\right)$ & $0.903^{* * *}$ & 0.202 \\
\hline$p$-value & 0.000 & 0.352 \\
\hline$\Sigma_{k=0}^{3}\left(M P_{t-k}^{E A} \cdot P r u_{j, t-1}^{R o W}\right)$ & $1.089^{* * *}$ & 0.233 \\
\hline$p$-value & 0.000 & 0.376 \\
\hline \multirow[t]{2}{*}{$\operatorname{Pru} u_{j, t-1}^{R o W}$} & $0.005^{* *}$ & -0.000 \\
\hline & $(0.002)$ & $(0.003)$ \\
\hline \multirow[t]{2}{*}{$\log (\text { Total Assets })_{t-1}$} & -0.164 & -0.077 \\
\hline & $(0.107)$ & $(0.070)$ \\
\hline \multirow[t]{2}{*}{ Capital Ratio $_{t-1}$} & -0.007 & -0.014 \\
\hline & $(0.014)$ & $(0.011)$ \\
\hline \multirow[t]{2}{*}{ Liquid Asset Ratio $_{t-1}$} & -0.003 & $0.009^{* *}$ \\
\hline & $(0.003)$ & $(0.004)$ \\
\hline \multirow[t]{2}{*}{ Core Deposits Ratio $_{t-1}$} & -0.004 & 0.000 \\
\hline & $(0.004)$ & $(0.003)$ \\
\hline \multirow[t]{2}{*}{ Commitment Share $_{t-1}$} & -0.014 & -0.003 \\
\hline & $(0.009)$ & $(0.006)$ \\
\hline \multirow[t]{2}{*}{ International Share $_{t-1}$} & -0.005 & -0.003 \\
\hline & $(0.006)$ & $(0.004)$ \\
\hline \multirow[t]{2}{*}{ Annual GDP Growth $h_{t-4}^{d e s t}$} & -0.005 & -0.006 \\
\hline & $(0.014)$ & $(0.017)$ \\
\hline \multirow[t]{2}{*}{ Credit to GDP Growth $h_{t-1}^{\text {dest }}$} & $-2.186^{* * *}$ & -1.082 \\
\hline & $(0.664)$ & $(0.741)$ \\
\hline Time FE & NO & $\mathrm{NO}$ \\
\hline Bank FE & YES & YES \\
\hline Receiving Country FE & YES & YES \\
\hline Observations & 626 & 863 \\
\hline R-squared & 0.15 & 0.08 \\
\hline Adjusted R-squared & 0.06 & 0.00 \\
\hline \multicolumn{3}{|c|}{$\begin{array}{l}\text { Notes. Dependent variable is quarterly \% change in cross-border lending, winsorised at the } 10 \% \text { level. } \\
\text { Prudential policy measure is the sum of prudential policy actions (excluding reserve requirements) } \\
\text { over a 2-year period, averaged across the world (excluding the euro area and the UK). FR sample: } \\
\text { 2000Q1-2013Q2. Standard errors, in brackets, are clustered by bank and time. Banks are differentiatec } \\
\text { by GSIB and non-GSIB status. }\end{array}$} \\
\hline
\end{tabular}


Table A6a: Interactions between euro area monetary policy and recipient-country prudential policy for the cross-border lending of affiliates in the UK using 24-month surprise change in euro area OIS rate

\begin{tabular}{|c|c|c|c|c|}
\hline & \multicolumn{2}{|c|}{ French-owned UK affiliates in the UK } & \multirow{2}{*}{$\begin{array}{c}\begin{array}{c}\text { EA-owned UK } \\
\text { affiliates }\end{array} \\
(3)\end{array}$} & \multirow{2}{*}{$\begin{array}{l}\text { UK-owned } \\
\text { banks in the } \\
\text { UK } \\
(4)\end{array}$} \\
\hline & (1) & (2) & & \\
\hline & All destinations & $\begin{array}{c}\text { Excluding } v i s-a ̀-v i s \\
\text { EA }\end{array}$ & All destinations & All destinations \\
\hline$\Sigma_{k=0}^{0}\left(M P_{t-k}^{E A} \cdot \operatorname{Pr} u_{j, t-4}^{d e s t}\right)$ & $0.217^{* * *}$ & $0.249^{* * *}$ & $0.097^{* * *}$ & -0.006 \\
\hline$p$-value & 0.003 & 0.005 & 0.003 & 0.890 \\
\hline$\Sigma_{k=0}^{1}\left(M P_{t-k}^{E A} \cdot \operatorname{Pru}_{j, t-4}^{\text {dest }}\right)$ & $0.317^{* *}$ & $0.372^{* *}$ & $0.155^{* * *}$ & 0.002 \\
\hline$p$-value & 0.010 & 0.017 & 0.005 & 0.982 \\
\hline$\Sigma_{k=0}^{2}\left(M P_{t-k}^{E A} \cdot P r u_{j, t-4}^{\text {dest }}\right)$ & $0.424^{* *}$ & $0.492^{* *}$ & $0.205^{* * *}$ & 0.038 \\
\hline$p$-value & 0.011 & 0.021 & 0.004 & 0.676 \\
\hline$\Sigma_{k=0}^{3}\left(M P_{t-k}^{E A} \cdot \operatorname{Pr} u_{j, t-4}^{d e s t}\right)$ & $0.440^{* *}$ & $0.479^{*}$ & $0.238^{* * *}$ & 0.056 \\
\hline$p$-value & 0.025 & 0.0562 & 0.004 & 0.599 \\
\hline \multirow{2}{*}{$\operatorname{Pru} u_{j, t-4}^{\text {dest }}$} & 0.001 & 0.002 & 0.003 & 0.001 \\
\hline & $(0.006)$ & $(0.008)$ & $(0.002)$ & $(0.003)$ \\
\hline \multirow[t]{2}{*}{$\log (\text { Total Assets })_{t-1}$} & $-0.027^{*}$ & -0.029 & $-0.013^{* *}$ & $0.033^{* *}$ \\
\hline & $(0.015)$ & $(0.023)$ & $(0.006)$ & $(0.014)$ \\
\hline \multirow[t]{2}{*}{ Capital Ratio $_{t-1}$} & -0.102 & -0.178 & -0.098 & -0.115 \\
\hline & $(0.115)$ & $(0.153)$ & $(0.061)$ & $(0.092)$ \\
\hline \multirow[t]{2}{*}{ Liquid Asset Ratio $_{t-1}$} & 0.109 & 0.136 & 0.029 & $0.094^{*}$ \\
\hline & $(0.072)$ & $(0.095)$ & $(0.021)$ & $(0.056)$ \\
\hline \multirow[t]{2}{*}{ Core Deposits Ratio $_{t-1}$} & -0.088 & -0.126 & 0.026 & -0.054 \\
\hline & $(0.116)$ & $(0.163)$ & $(0.036)$ & $(0.044)$ \\
\hline \multirow[t]{2}{*}{ Commitment Share St-1 $_{1}$} & -0.005 & 0.009 & 0.018 & $0.100^{*}$ \\
\hline & $(0.056)$ & $(0.083)$ & $(0.018)$ & $(0.058)$ \\
\hline \multirow[t]{2}{*}{ International Share $_{t-1}$} & -0.035 & -0.003 & $-0.088^{* * *}$ & $-0.333^{* * *}$ \\
\hline & $(0.079)$ & $(0.101)$ & $(0.028)$ & $(0.070)$ \\
\hline \multirow[t]{2}{*}{ Annual GDP Growth $h_{t-4}^{d e s t}$} & 0.219 & 0.186 & $0.284^{* * *}$ & 0.133 \\
\hline & $(0.282)$ & $(0.400)$ & $(0.102)$ & $(0.143)$ \\
\hline \multirow[t]{2}{*}{ Credit to GDP Growth $h_{t-1}^{\text {dest }}$} & 0.040 & 0.011 & $0.056^{* *}$ & $0.072^{* *}$ \\
\hline & $(0.059)$ & $(0.073)$ & $(0.023)$ & $(0.031)$ \\
\hline Time FE & YES & YES & YES & YES \\
\hline Bank FE & YES & YES & YES & YES \\
\hline Receiving Country FE & YES & YES & YES & YES \\
\hline Observations & 10,519 & 6,388 & 54,655 & 28,205 \\
\hline R-squared & 0.025 & 0.027 & 0.021 & 0.023 \\
\hline Adjusted R-squared & 0.012 & 0.007 & 0.017 & 0.017 \\
\hline \multicolumn{5}{|c|}{$\begin{array}{l}\text { Notes. Dependent variable is quarterly \% change in cross-border lending, winsorised at the } 10 \% \text { level. Prudential policy measure is the sum } \\
\text { of prudential policy actions (excluding reserve requirements) over a 2-year period. UK sample: } 2000 \mathrm{Q} 1-2017 \mathrm{Q} 4 \text {. Standard errors, in } \\
\text { brackets, are clustered by bank and time. Euro area monetary policy measure is the } 24 \text {-month euro area OIS rate surprise. }\end{array}$} \\
\hline
\end{tabular}


Table A6b: Interactions between euro area monetary policy and recipient-country prudential policy for the cross-border lending of affiliates in the UK using prudential policy indicator that includes reserve requirements

\begin{tabular}{|c|c|c|c|c|}
\hline & \multicolumn{2}{|c|}{ French-owned UK affiliates in the UK } & \multirow{2}{*}{$\begin{array}{c}\text { EA-owned UK } \\
\text { affiliates } \\
\text { (3) }\end{array}$} & \multirow{2}{*}{$\begin{array}{c}\text { UK-owned } \\
\text { banks in the } \\
\text { UK } \\
(4)\end{array}$} \\
\hline & (1) & (2) & & \\
\hline & All destinations & $\begin{array}{c}\text { Excluding } v i s-a ̀-v i s \\
\text { EA }\end{array}$ & All destinations & All destinations \\
\hline$\Sigma_{k=0}^{0}\left(M P_{t-k}^{E A} \cdot P r u_{j, t-4}^{d e s t}\right)$ & $0.197^{* *}$ & $0.277^{* *}$ & $0.087^{* *}$ & -0.015 \\
\hline$p$-value & 0.035 & 0.021 & 0.046 & 0.786 \\
\hline$\Sigma_{k=0}^{1}\left(M P_{t-k}^{E A} \cdot \operatorname{Pru}_{j, t-4}^{\text {dest }}\right)$ & 0.202 & 0.301 & $0.117^{*}$ & -0.0396 \\
\hline$p^{\text {-value }}$ & 0.177 & 0.114 & 0.087 & 0.656 \\
\hline$\Sigma_{k=0}^{2}\left(M P_{t-k}^{E A} \cdot P r u_{j, t-4}^{\text {dest }}\right)$ & 0.220 & 0.342 & $0.156^{*}$ & 0.009 \\
\hline$p^{\text {-value }}$ & 0.293 & 0.197 & 0.080 & 0.932 \\
\hline$\Sigma_{k=0}^{3}\left(M P_{t-k}^{E A} \cdot P r u_{j, t-4}^{\text {dest }}\right)$ & 0.099 & 0.192 & $0.173^{*}$ & 0.049 \\
\hline$p$-value & 0.699 & 0.545 & 0.095 & 0.715 \\
\hline \multirow[t]{2}{*}{$\operatorname{Pru} u_{j, t-4}^{\text {dest }}$} & -0.003 & -0.005 & -0.000 & 0.001 \\
\hline & $(0.004)$ & $(0.005)$ & $(0.002)$ & $(0.002)$ \\
\hline \multirow[t]{2}{*}{$\log (\text { Total Assets })_{t-1}$} & $-0.026^{*}$ & -0.029 & $-0.013^{* *}$ & $0.0325^{* *}$ \\
\hline & $(0.014)$ & $(0.023)$ & $(0.006)$ & $(0.014)$ \\
\hline \multirow[t]{2}{*}{ Capital Ratio $_{t-1}$} & -0105 & -0.183 & -0.098 & -0.114 \\
\hline & $(0.116)$ & $(0.153)$ & $(0.061)$ & $(0.092)$ \\
\hline \multirow[t]{2}{*}{ Liquid Asset Ratio $_{t-1}$} & 0.109 & 0.137 & 0.029 & $0.094^{*}$ \\
\hline & $(0.072)$ & $(0.095)$ & $(0.021)$ & $(0.056)$ \\
\hline \multirow[t]{2}{*}{ Core Deposits Ratio $_{t-1}$} & -0.089 & -0.129 & 0.026 & -0.054 \\
\hline & $(0.117)$ & $(0.163)$ & $(0.036)$ & $(0.044)$ \\
\hline \multirow[t]{2}{*}{ Commitment Share $e_{t-1}$} & -0.005 & 0.010 & 0.018 & $0.100^{*}$ \\
\hline & $(0.056)$ & $(0.083)$ & $(0.018)$ & $(0.058)$ \\
\hline \multirow[t]{2}{*}{ International Share $_{t-1}$} & -0.036 & -0.006 & $-0.087^{* * *}$ & $-0.3326^{* * *}$ \\
\hline & $(0.079)$ & $(0.102)$ & $(0.028)$ & $(0.070)$ \\
\hline \multirow[t]{2}{*}{ Annual GDP Growth $h_{t-4}^{\text {dest }}$} & 0.256 & 0.224 & $0.291^{* * *}$ & 0.128 \\
\hline & $(0.278)$ & $(0.395)$ & $(0.102)$ & $(0.143)$ \\
\hline \multirow[t]{2}{*}{ Credit to GDP Growth $h_{t-1}^{\text {dest }}$} & 0.037 & 0.008 & $0.057^{* *}$ & $0.073^{* *}$ \\
\hline & $(0.059)$ & $(0.073)$ & $(0.023)$ & $(0.031)$ \\
\hline Time FE & YES & YES & YES & YES \\
\hline Bank FE & YES & YES & YES & YES \\
\hline Receiving Country FE & YES & YES & YES & YES \\
\hline Observations & 10,519 & 6,388 & 54,655 & 28,205 \\
\hline R-squared & 0.025 & 0.027 & 0.021 & 0.023 \\
\hline Adjusted R-squared & 0.012 & 0.007 & 0.016 & 0.017 \\
\hline \multicolumn{5}{|c|}{$\begin{array}{l}\text { Notes. Dependent variable is quarterly \% change in cross-border lending, winsorised at the } 10 \% \text { level. Prudential policy measure is the sum } \\
\text { of prudential policy actions (including reserve requirements) over a 2-year period. UK sample: 2000Q1-2017Q4. Standard errors, in } \\
\text { brackets, are clustered by bank and time. Euro area monetary policy measure is the 6-month euro area OIS rate surprise. }\end{array}$} \\
\hline
\end{tabular}


Table A6c: Interactions between euro area monetary policy and recipient-country prudential policy for the cross-border lending of affiliates in the UK using a 2000Q1-2013Q2 sample to match French dataset

\begin{tabular}{|c|c|c|c|c|}
\hline & \multicolumn{2}{|c|}{ French-owned UK affiliates in the UK } & \multirow{2}{*}{$\begin{array}{c}\begin{array}{c}\text { EA-owned UK } \\
\text { affiliates }\end{array} \\
\text { (3) }\end{array}$} & \multirow{2}{*}{$\begin{array}{c}\text { UK-owned } \\
\text { banks in the } \\
\text { UK } \\
(4)\end{array}$} \\
\hline & (1) & (2) & & \\
\hline & All destinations & $\begin{array}{c}\text { Excluding } v i s-a ̀-v i s \\
\text { EA }\end{array}$ & All destinations & All destinations \\
\hline$\Sigma_{k=0}^{0}\left(M P_{t-k}^{E A} \cdot P r u_{j, t-4}^{d e s t}\right)$ & $0.243^{* *}$ & $0.342^{* *}$ & 0.040 & -0.018 \\
\hline$p$-value & 0.019 & 0.013 & 0.445 & 0.765 \\
\hline$\Sigma_{k=0}^{1}\left(M P_{t-k}^{E A} \cdot \operatorname{Pru}_{j, t-4}^{\text {dest }}\right)$ & 0.250 & $0.427^{* *}$ & 0.054 & -0.034 \\
\hline$p^{\text {-value }}$ & 0.135 & 0.045 & 0.508 & 0.723 \\
\hline$\Sigma_{k=0}^{2}\left(M P_{t-k}^{E A} \cdot \operatorname{Pr} u_{j, t-4}^{\text {dest }}\right)$ & 0.273 & $0.532^{*}$ & 0.103 & 0.022 \\
\hline$p^{\text {-value }}$ & 0.239 & 0.074 & 0.332 & 0.853 \\
\hline$\Sigma_{k=0}^{3}\left(M P_{t-k}^{E A} \cdot P r u_{j, t-4}^{\text {dest }}\right)$ & 0.183 & 0.413 & 0.168 & 0.074 \\
\hline$p$-value & 0.516 & 0.251 & 0.165 & 0.613 \\
\hline \multirow[t]{2}{*}{$\operatorname{Pru} u_{j, t-4}^{\text {dest }}$} & -0.003 & 0.001 & -0.001 & 0.001 \\
\hline & $(0.008)$ & $(0.010)$ & $(0.003)$ & $(0.004)$ \\
\hline \multirow[t]{2}{*}{$\log (\text { Total Assets })_{t-1}$} & $-0.030^{*}$ & -0.034 & $-0.019^{* *}$ & 0.022 \\
\hline & $(0.017)$ & $(0.026)$ & $(0.009)$ & $(0.026)$ \\
\hline \multirow[t]{2}{*}{ Capital Ratio $_{t-1}$} & -0.018 & -0.054 & -0.160 & -0.197 \\
\hline & $(0.133)$ & $(0.165)$ & $(0.122)$ & $(0.122)$ \\
\hline \multirow[t]{2}{*}{ Liquid Asset Ratio $_{t-1}$} & $0.174^{* *}$ & $0.205^{* *}$ & 0.009 & $0.176^{* *}$ \\
\hline & $(0.077)$ & $(0.095)$ & $(0.026)$ & $(0.072)$ \\
\hline \multirow[t]{2}{*}{ Core Deposits Ratio $_{t-1}$} & $-0.299^{*}$ & -0.303 & 0.015 & -0.081 \\
\hline & $(0.169)$ & $(0.239)$ & $(0.042)$ & $(0.055)$ \\
\hline \multirow[t]{2}{*}{ Commitment Share $e_{t-1}$} & 0.046 & 0.070 & 0.009 & $0.192^{* * *}$ \\
\hline & $(0.065)$ & $(0.103)$ & $(0.024)$ & $(0.071)$ \\
\hline \multirow[t]{2}{*}{ International Share $_{t-1}$} & $-0.185^{* *}$ & -0.145 & $-0.118^{* * *}$ & $-0.482^{* * *}$ \\
\hline & $(0.094)$ & $(0.122)$ & $(0.038)$ & $(0.090)$ \\
\hline \multirow[t]{2}{*}{ Annual GDP Growth $h_{t-4}^{\text {dest }}$} & 0.077 & -0.106 & $0.239^{*}$ & 0.249 \\
\hline & $(0.358)$ & $(0.478)$ & $(0.129)$ & $(0.175)$ \\
\hline \multirow[t]{2}{*}{ Credit to GDP Growth $h_{t-1}^{\text {dest }}$} & 0.038 & 0.018 & $0.063^{* *}$ & $0.076^{* *}$ \\
\hline & $(0.068)$ & $(0.085)$ & $(0.028)$ & $(0.036)$ \\
\hline Time FE & YES & YES & YES & YES \\
\hline Bank FE & YES & YES & YES & YES \\
\hline Receiving Country FE & YES & YES & YES & YES \\
\hline Observations & 7,778 & 4,702 & 34,942 & 20,759 \\
\hline R-squared & 0.030 & 0.031 & 0.024 & 0.025 \\
\hline Adjusted R-squared & 0.015 & 0.008 & 0.019 & 0.018 \\
\hline \multicolumn{5}{|c|}{$\begin{array}{l}\text { Notes. Dependent variable is quarterly \% change in cross-border lending, winsorised at the } 10 \% \text { level. Prudential policy measure is the sum } \\
\text { of prudential policy actions (excluding reserve requirements) over a 2-year period. UK sample: 2000Q1-2013Q2 (matching French dataset). } \\
\text { Standard errors, in brackets, are clustered by bank and time. Euro area monetary policy measure is the 6-month euro area OIS rate surprise. }\end{array}$} \\
\hline
\end{tabular}

